\title{
LAS INUNDACIONES DEL XÚQUER (SIGLOS XV-XIX), UN EXPONENTE RELEVANTE DE LA CUESTIÓN HIDRÁULICA EN TIERRAS VALENCIANAS*
}

\author{
Tomás PERIS ALBENTOSA \\ IES Arabista Ribera (Carcaixent)
}

\begin{abstract}
Resumen
El presente artículo trata de analizar las principales características de las inundaciones del Júcar en la comarca valenciana de la Ribera -en el curso bajo de este río- entre mediados del siglo XV y finales del XIX. Se hace especial hincapié en los factores naturales y antrópicos que provocaban los desbordamientos, así como en las consecuencias de todo tipo generadas y las respuestas adoptadas para tratar de paliar los efectos destructores de las riadas.

Palabras clave: Inundaciones, irregularidades pluviométricas, infraestructuras hidráulicas, catástrofes naturales, agricultura irrigada, historia del clima.
\end{abstract}

\begin{abstract}
This article tries to analyze the main aspects of the rivers Júcar in the valencian region of La Ribera -in the lower course of this river- between the middle of the $15^{\text {th }}$ century and the end of the $19^{\text {th }}$. The article emphasizes the natural and anthropological factors that caused the floodings and both the consequences of all type and the responses adopted to try to palliate the destructive effects of the floods.

Key words: Floods, rainfall irregularity, hydraulic infrastructure, natural catastrophes, irrigated farming, history of climate.
\end{abstract}

\footnotetext{
* El presente trabajo se inscribe en el proyecto de investigación BHA2002-01551 titulado «Clima, agricultura y sociedad en la España del siglo XVIIl» financiado por el Ministerio de Educación y Ciencia y fondos FEDER.
} 
Las tierras que rodean al Mediterráneo han sido un medio duro para las gentes que las ocupaban. 'Muy al contrario del tópico del 'Levante feliz' que suele aplicarse al territorio valenciano, las dificultades naturales - entre las que sobresale el problema del agua- han significado un reto difícil que era necesario resolver para lograr sobrevivir. Las riadas del Xúquer constituyen un ejemplo fundamental que revela los complejos nexos existentes entre clima y economía agraria en las sociedades tradicionales. Además, la crónica irregularidad pluviométrica se manifestaba en forma de alternancia entre sequías y temporales de lluvias que afectaban -tanto o más que las propias inundaciones - al normal desarrollo del ciclo agrícola. Y no era extraño que heladas y pedriscos destrozaran las cosechas.

\section{LAS DIVERSAS MANIFESTACIONES DEL PROBLEMA DEL AGUA EN LA RIBERA DEL XÚQUER: SEQUÍAS, TEMPORALES Y TORMENTAS}

La comarca estudiada sufrió, entre los siglos XV-XIX, toda la gama de problemas que origina el déficit o el exceso de agua. Una lluvia tan vital como mal repartida y el relieve de la comarca provocaban -según donde y cuando- encharcamientos de aguas o falta de sazón parar criar las cosechas. Sequías, temporales y tormentas fueron fenómenos endémicos que nunca dejaron de amenazar a la precaria economía campesina. Las comunidades rurales respondieron al reto mediante diversas estrategias adaptativas; la principal consistió en reservar los secanos para cultivos arbóreos, amoldados a la aridez ambiental, ${ }^{2}$ y concentrar los esfuerzos productivos en las huertas. ${ }^{3}$

\subsection{Los perniciosos temporales de lluvias}

El antiguo régimen (en especial la segunda mitad del siglo XVIII) fue una fase climática más pluviosa en la Ribera del Xúquer. ${ }^{4} \mathrm{El}$ agua igual se recibía como lluvias beneficiosas para el campo o bien en forma de precipitaciones torrenciales o tempora-

1. Como puso de relieve en su día Fernand BRAUDEL en su clásico estudio El Mediterráneo y el mundo mediterráneo en la época de Felipe $I I$, vol. I, Madrid, FCE, 1976, págs. 75-91, 314-323 y 343-364.

2. Como algarrobos, olivos y vides, cuyas raíces profundizaban en tierra buscando humedad.

3. El abandono de los secanos de la Ribera ya fue subrayado por A. J. CAVANILLES. Al tratar del término de Alzira, afirmaba que «todos ponen sus conatos en cultivar las huertas, huertos y arrozales, donde consumen una inmensa cantidad de estiércol [...], los secanos se miran con poco afecto, y aunque iguales en extensión a quanto logra riego, es muy poco el fruto que producen». Un contraste similar se daba en la mayor parte de la comarca. Por ejemplo, sobre Massalavés informa que «de secano hay 3.000 hanegadas, que están poco menos que abandonadas por falta de brazos y porque el cultivo del arroz se lleva toda la atención» (Observaciones sobre la Historia Natural, Geografia, Agricultura, Población y Frutos del Reyno de Valencia, Madrid, Imprenta Real, 1795-97, vol. I, págs. 196 y 208).

4. Un indicio elocuente lo proporciona el barranco Gran del valle de Aigües Vives. Ahora permanece casi siempre seco, mientras que en la época estudiada discurría un caudal perenne por él, que permitia funcionar a los molinos de Fracà y l'Estret, posibilitaba multiplicar los campos de arroz -cultivo de primavera y verano- y explica que abundaran los peces en su lecho (F. FOGUÉs JUAN: Historia y iradición de la Virgen de Aguas Vivas, patrona de Carcaixent, Carcaixent, Cofradía de Aguas Vivas, 1982, págs. 4-16). 
les capaces de colapsar el ciclo agrario. Estas últimas adversidades climáticas fueron cada vez más frecuentes y perniciosas. Un motivo básico fue la expansión del regadío, que indujo a concentrar los esfuerzos productivos en las huertas, reduciendo la entidad económica del secano. Semanas y semanas de lluvia fina impedían sembrar a tiempo, pudrían la simiente y llegaban al extremo de ahogar los árboles existentes en el llano de inundación -formado por aluviones arcillosos poco permeables-, allí donde el manto freático estaba muy alto. ${ }^{5}$ Los daños en la huerta alcanzaban a ser tan ingentes ${ }^{6}$ que no podían compensarse con la mayor producción del secano en esos años lluviosos (puesto que olivos, algarrobos y viñedos tenían una entidad muy secundaria en la economía agraria de la zona). ${ }^{7}$

Los temporales llegaron a ser muy persistentes en la Ribera. ${ }^{8}$ En 1475 , estuvo lloviendo casi sin cesar-según Fogués-durante cuatro meses. Otras lloviznas muy pertinaces fueron las de 1605, 1672 y 1695, en las que llovió durante tres meses, y 1783, que duró casi 70 días. Pero incluso temporales bastante más cortos podían llegar a ser muy ruinosos si las precipitaciones se producían en momentos críticos (como cuando había que recoger la hoja de las moreras para alimentar a los gusanos de seda -marzo, abril y mayo-, como sucedió en 1781, 1783 o 1794). En sentido contrario, temporales muy duraderos (como el de 1695, que se mantuvo de octubre a diciembre) ocasionaron pocos daños al campo debido al momento concreto del calendario agrícola en que se produjeron, aunque suscitaron otro tipo de calamidades, en especial el hundimiento de numerosos edificios. Muy relevante es el cambio que se constata entre 1750 y 1790 , ya que los temporales fueron más frecuentes durante estas décadas y -además-bastantes se produjeron en años de fuerte riada $(1752,1766,1783-86$ y 1794), circunstancia que antes había sido excepcional. ${ }^{9}$

V. I. Franco subrayó el problema del exceso de humedad que sufrían las huertas de la Ribera Alta al final del setecientos. Además de las lluvias persistentes, las causas apuntadas eran las «copiosas avenidas y frecuentes aluviones» de los ríos, así como las filtraciones de las acequias. El resultado era que la huerta se convertía en un «terreno de naturaleza húmeda» y muchos lugares hondos acababan convertidos en «aguasares». El problema afectaba de forma global al rendimiento de las cosechas en el conjunto de la comarca, ya que «los ayres se llenan de densas nieblas, que derrama-

5. T. PERIS AlBeNTOSA: Propiedad y cambio social. Alzira (1465-1768), Valencia, Diputación de Valencia, 1989 , pág. 187.

6. Muchos lugares hondos, enclavados dentro del perímetro irrigado, no pudieron cultivarse hasta fechas tardias por estar cubiertos casi siempre por aguas (solian aprovecharse como zonas de pastoreo).

7. T. PERis Albentosa: La terra de l'arròs i les moreres, Alzira, Bromera, 2003, págs. 125-131.

8. Véase al respecto mi libro L'escenari i els protagonistes, Alzira, Bromera, 2001, págs. 95-96 y 231-232.

9. Sólo en 1672 estuvo lloviendo durante tres meses y se produjo una importante riada. El temor a los perjuicios que ocasionaban los temporales de lluvia impulsó a la población ribereña a celebrar frecuentes rogativas religiosas e incluso institucionalizar un toque específico de campanas -«de temporal»-con el que se pretendía implorar la clemencia divina y conseguir que cesaran las lluvias (E. SARRIÓ: El Capbreu d'Albalat de la Ribera de 1636, Albalat, Ajuntament d'Albalat, 1998, pág. 60). 
das sobre los frutos y heridos éstos de los rayos picantes del sol, anublan y corroen los granos del trigo $\% .{ }^{10}$ Como los escritos de Franco tenían como objetivo convencer a las autoridades borbónicas de la necesidad de permitir el cultivo del arroz, resulta legítimo pensar que pudo exagerar las humedades que se padecían en la Ribera Alta. Por eso resulta conveniente acudir a testimonios neutrales que describan el contexto ecológico y climático de la comarca al margen de polémicas entre partidarios del arroz e interesados en el negocio del binomio morera-seda. Muy recomendable es la Topografia Médica General de la Ribera del Xúcar, escrita por F. Llansol en 1797, donde se explica. la pluviosidad de la comarca como resultado del choque de vientos húmedos de levante (saturados al atravesar la zona) con las montañas del oeste:

Las lluvias suelen ser muy molestas en los inviernos en toda esta vega [...;] esto se verifica más en aquellos lugares que, inmediatos al mar, tienen valles citcuidos de montes que embarazan la corriente de aire. Por este motivo, y por la humedad que suministra la atmósfera, con tantas balsas y lagunas empleadas en la cría de arroz, tantas azequias, barrancos y azarbes, tantas balsas para regar los huertos (pues desde el término de Carcaixent hasta los confines de Poliñá hai cerca de mil), se halla aquí gran disposición a las lluvias. Los montes occidentales de la Garrofera, de una altitud considerable, [...] son otros tantos embarazos al levante que sale del mar con mucha humedad, y va embebiendo la atmósfera $[\ldots]]^{! 1}$

\subsection{Los abundantes periodos de sequía}

Es propio del clima mediterráneo que los temporales alternen con etapas secas. No resultaba extraño, pues, que el final de una de estas calamidades no diera paso a una fase de normalidad pluviométrica sino que enlazara con un desastre de signo contrario. ${ }^{12}$ En el País Valenciano, se produjeron importantes sequías durante la primera mitad del seiscientos y en la centuria siguiente fueron graves las de 1722, 1725-30, la fase 1748-1753, así como bastantes años entre $1770 \mathrm{y}$ el final del siglo. ${ }^{13}$

El impacto de las sequías fue bastante reducido en la Ribera debido a la amplitud alcanzada por el regadío. Las noticias de falta de agua se limitan a 1604, 1631, 1651, $1661,1702,1756,1758-59,1766$ y $1807-1810$. Parece ser que la peor sequedad fue la de 1661, ya que fue larga, afectó a las cosechas en momentos críticos (en Carcaixent impidió sembrar) y perjudicó a gran parte de la comarca. A diferencia de heladas y temporales, las sequías se manifiestan como una calamidad meteorológica localizada

10. Cit. V. RIBES IBORRA: La Ilustración marginada: Vicente I. Franco, Valencia. Diputación de Valencia y UNED Alzira, 1987, pág. 69.

11. Trascrito en J. Riera PALMERO y J. GRANDA Juesas: Epidemias y paludismo en la Ribera del Jicar (tma topografia médica del siglo XVIII), Valladolid, Universidad de Valladolid, 1988, págs. 104-105.

12. Es lo que sucedió -por ejemplo- en 1766, cuando el temporal de lluvias de octubre y noviembre fuc seguido por una sequia a partir de diciembre.

13. A. Alberola RomA: Catástrofe, economia y acción politica en la Valencia del siglo Xrill, Valencia, Alfons el Magnànim, 1999, págs. 36-38 53-55, 175-185, 289 y 322-330. 
y menos grave. Las huertas ribereñas mejor dotadas hídricamente ${ }^{14}$ casi no conocieron sequías relevantes. Otros perímetros irrigados abastecidos con los caudales más irregulares del Albaida o el Magro padecieron penurias puntuales, que acentuaban la conflictividad entre regantes y mermaban los rendimientos de las cosechas.

Las zonas más perjudicadas por las sequías fueron aquellos términos en los que la proporción de tierras regadas era menor (como Benifaió, Almussafes y Sollana), así como las áreas ubicadas al final de los sistemas de riego -Algemesí- o de la cuenca fluvial (Cullera). Así, Sollana sufrió graves sequedades. En la de 1455-56 se llegó al extremo de faltar el agua para el consumo humano y la de 1661 provocó graves daños en las cosechas. La sequía de 1758-59 fue tan larga e intensa como para impulsar al duque de Hijar a invertir más de dos millones de libras para construir la acequia del Proyecto, que puso en riego 6.600 hectáreas entre Algemesí y Albal. Con el riego se evitaba que la carencia de sazón en otoño impidiera sembrar, que la falta de agua en primavera obstaculizara la granazón de los cereales o que la ausencia de lluvias en verano no dejara labrar los campos en barbecho. Otra zona afectada por sequías fue Cullera, a mitad del siglo XVII y en 1807-1810, cuando la falta de agua provocó que el hambre hiciera sentir «sus tristes efectos hasta en las clases más acomodadas»». ${ }^{15}$

\subsection{Las peligrosas tormentas}

Las tormentas con granizo eran adversidades climatológicas más localizadas que los temporales o las sequías. ${ }^{16}$ Las primeras noticias sobre este tipo de tempestades que ofrece la bibliografía ribereña son ya del siglo XVII. En 1605, este meteoro arruinó la cosecha de trigo de la comarca. En agosto de 1620, una gran tempestad ocasionó graves daños en los campos y en los tejados de las casas. Y el 25 de septiembre de 1663, una gran tormenta dejó caer piedras «tan gruesas como naranjas», que destrozaron Carcaixent y su término. ${ }^{17}$

La peor granizada del XVIII fue la que afectó a Corbera en 1757. El pedrisco de finales de septiembre devastó la cosecha de arroz, que se encontraba a punto de segar, y produjo importantes daños en algarrobos y olivos. Las pérdidas fueron evaluadas en más de 44.000 libras (cifra que duplica los desperfectos ocasionados por el famoso terremoto de 1748 en toda la Ribera), provocando la ruina de unos campesinos que ya estaban en el límite de la miseria, ahogados por las demandas de los acreedores censalistas y la pesada cargas fiscales. ${ }^{18}$

14. En especial las que tomaban el agua en los primeros azudes del Xúquer, como la acequia Real de Alzira, la de Escalona y la de Carcaixent.

15. A. Piles Ibars i F. Giner Perepérez: Historia de Cullera, Valencia, Ajuntament de Cullera, reedición de 1972 , pág. 467.

16. Lina lectura poco crítica de los documentos provoca la impresión que las tormentas fucron cspecialmente calamitosas durante la segunda mitad del siglo XVIII; pero creo que esta percepción es más resultado de una mayor riqueza documental que de un agravamiento real de este tipo de meteoro.

17. Fogués: Historia de Carcagente..., Carcaixent, 1934, págs. 157-158.

18. AlBERoLA ROMA: Catástrofe, economia y acción politica..., págs. 201-203. 
Los motines de la década de 1760 produjeron tal alarma que las autoridades borbónicas se mantuvieron alerta para impedir que las exigencias tributarias superaran el límite a partir del cual el malestar pudiera desembocar en peligrosas revueltas. Así se entiende que los municipios afectados remitieran a la Secretaría de Hacienda informes en los que exponían los efectos del desastre climático sufrido y solicitaban medidas de gracia. En este contexto hay que situar los memoriales sobre las granizadas de 1791 y 1794, lo que obliga a ser extremamente cautos al leer sus datos. El pedrisco del 16-VI1791, que afectó a Benimuslem y Alzira, no fue tan grave como el de 1757. Los regidores exageraron los daños -4.210 libras- a fin de obtener licencia para plantar arroz fuera de los cotos establecidos en 1753 , pero las autoridades consideraron la petición excesiva (ya que el trigo estaba segado, los gusanos criados y el maíz poco crecido). En septiembre de 1794, el Marquesat sufrió otra tempestad de piedra que dañó las cosechas de aceite, vino, maíz y algarrobas. ${ }^{19}$

Lo que resulta incuestionable es la estacionalidad de las granizadas que afectaron la Ribera, un fenómeno concentrado entre mayo y septiembre. Las tormentas de abril y mayo afectaban a moreras y trigales. Pero las tempestades de verano eran más peligrosas incluso, ya que arruinaban los arrozales, una cosecha básica en el sistema agrario de la comarca.

\section{LA CRONOLOGÍA DE LOS DESBORDAMIENTOS DEL XÚQUER}

Las avenidas fluviales han sido un fenómeno general en el mundo mediterráneo. En la Ribera del Xúquer, las riadas alcanzaron un protagonismo extraordinario; pero -sorprendentemente- su relevancia no se ve reflejada en la historiografia, mucho más endeble de lo que seria coherente y deseable. ${ }^{20}$

Un primer aspecto a precisar es la cronología de los desbordamientos, tanto por lo que se refiere a su estacionalidad como a la distribución anual. El régimen de los ríos que atraviesan la Ribera y la pluviometría de la comarca explican el reparto estacional

19. Por lo que se solicitó una rebaja del equivalente (ALBEROLA ROMÁ: op. cit., págs. 314-316). Afortunadamente, muchas tormentas quedaron en fuertes sustos y no llegaron a ocasionar desperfectos (un magnífico ejemplo del pánico provocado por estos meteoros lo constituye la tormenta del 5 de mayo de 1748 en Carcaixent (F. FoGUÉs: Historia y tradición ..., págs. 235-237).

20. Las excepciones más meritorias a esta dejadez son el monográfico dedicado por Cuadernos de Geografia, poco después de la 'pantanada' de 1982, y el conjunto de trabajos publicados por el profesor Joan MATEU. La tesis doctoral de José Manuel RuIZ PÉRez sobre la evolución de los meandros del Xúquer representa un notable avance. Por último, cabe reseñar que la sesión monográfica de la $X$ Assemblea d'Història de la Ribera (celebrada en Antella los días 5-7 de noviembre de 2004) se ha dedicado al estudio de Riuades $i$ inundacions a la Ribera del Xúquer en la perspectiva històrica. En dicho encuentro se presentaron las ponencias de P. CARMONA («Les inundacions històriques del Xúquer a través del registre geo-arqueològic»), J. M. RUIZ ( «Inundacions durant la petita Edat del Gel en els rius Xúquer i Túria, segles XIV i XV»), V. ROSSELLÓ («Riuades i inundacions en la Ribera del Xúquer en la perspectiva històrica», T. PËRIS («EIs efectes de les revingudes del Xúquer a la Ribera durant l'antic règim») y S. CALATAYUD («La revinguda de 1864), asi como diversas comunicaciones. Todos estos textos serán publicados por la Universidad de Valencia. 
de las riadas. Buena parte de las avenidas más recordadas se produjeron durante el otoño, entre mitad de septiembre y principio de noviembre. Las inundaciones primaverales también abundaron $(1690,1752,1775,1794$ y 1802), mientras que las riadas invernales no fueron tan extrañas como podría pensarse $(1627,1795,1814$, etc.). Como los desbordamientos responden a fenómenos climáticos de magnitud excepcional, es posible encontrar inundaciones en cualquier momento del año, incluso durante aquellos meses en que resultaría más adecuado pensar en la típica sequía mediterránea. ${ }^{21} \mathrm{El}$ Dictamen facultativo... de Sancho y Monleón, de 1860, explicaba que «las avenidas ordinarias $[\ldots]$ acontecen generalmente por efecto del deshielo y de las lluvias en los meses de enero, febrero y marzo [... mientras que] las crecientes extraordinarias [...] ocurren por lo regular, aunque de tarde en tarde, de agosto en adelante». ${ }^{22} \mathrm{Y}$ la Memoria sobre la inundación del Júcar..., de M. Bosch Julià, perfilaba la estacionalidad de las peores riadas producidas hasta 1864 , concluyendo que:

[en...] 148 años se han registrado veinte y cuatro grandes avenidas del Júcar. De las veinte $y$ una en que se ha determinado el mes, dos corresponden a septiembre, cuatro a octubre, seis a noviembre, tres a diciembre, una a enero, una a febrero, una a marzo, una a abril, una a mayo [...] y una a julio. Agrupadas por estaciones, once han ocurrido en otoño, cinco en invierno, tres en primavera y una en verano; [...] las avenidas del Júcar ocurren casi siempre en otoño, particularmente en noviembre, en los alrededores de Todos Santos. ${ }^{23}$

Por lo que se refiere a la distribución anual de las avenidas fluviales, los datos muestran un agravamiento progresivo del fenómeno, con un cambio importante desde 1740. Si dividimos la etapa 1460-1810 en fases de 70 años, resulta que antes de 1740 el número de riadas fluctúa entre 6 y 10 en cada fase, ${ }^{24}$ mientras que entre 1740 y 1810 llegaron a existir 30 años con desbordamientos y sólo 40 libres de ellos. La peor coyuntura fue la comprendida entre 1773 y 1806 , ya que hubo más años con inundaciones graves que sin ellas -20 y 13 respectivamente- y, además, en este período se concentran tres riadas extremas $(1779,1791$ y 1805$)$. Se trata de un patente recrudecimiento del problema que cabe atribuir sobre todo a las anomalías climáticas que afectaron al conjunto del continente europeo durante esas décadas (aunque los cambios del llano

21. En 1590, las aguas del Xúquer se desbordaron en el mes de julio y en un año se produjeron 11 desbordamientos durante el invierno (LlANSOL: Topografía médica general..., pág. 107).

22. A. SANCHO y S. MONLEÓN: Dictamen facultativo sobre el proyecto formado por don Juan Bautista Peyronet..., Valencia, Imprenta Ayoldi, 1860, pág. 13.

23. Este ingeniero destacaba que el caudal del Xúquer no era regular, pero tampoco tan variable como otros ríos mediterráneos: «En mayo, junio y julio es cuando lleva más el Júcar; por la Virgen de Agosto ya refresca, como se dice en la Ribera, esto es, va aumentando su caudal; en setiembre nunca lleva poca agua; en octubre toma nuevos bríos; el mayor caudal baja en noviembre y diciembre, y hasta abril no afloja de una manera notable» (Memoria sobre la inundación del Jicar en 1864... Madrid, Imprenta Nacional, 1866, págs. 132-133).

24. Entre 1460 y 1530 o $1670-1740$ hubo 10 años con desbordamientos, mientras que entre 1600 y 1670 se registraron 8 y en la etapa 1530-1600 sólo hubo 6 años con inundaciones notables. Véanse las principales riadas del Xúquer en PerIS AlBentosa: L'escenari i els protagonistes..., págs. 100-104. 
de inundación -resultado del progresivo aluvionamento- también desempeñaron un papel relevante). ${ }^{25}$

\section{PRINCIPALES FACTORES DE LAS INUNDACIONES DEL XÚQUER}

Desde el siglo XVII, se ha mantenido un encendido debate sobre las causas que provocaban las riadas del Xúquer, polémica que ha evolucionado -intensificándose o languideciendo- de forma paralela a la intensidad de los efectos que provocaban. Los principales hitos de este debate hay que ubicarlos en las décadas centrales del siglo XVII -escritos de Racsas y Vincensi-, los años posteriores a la gran inundación de 1864 -trabajos de Bosch Julià y Gómez Ortega- asi como la década de $1980 .{ }^{26}$ Todos los participantes en estas controversias coinciden en explicar las riadas como resultado complejo de una serie de rasgos naturales (características de la cuenca baja del Xúquer, anomalías climáticas, etc.) y un conjunto de actuaciones antrópicas perjudiciales (construcción de infraestructuras que afectaban al drenaje de las aguas, deforestación de la cuenca, etc.).

\subsection{Los factores naturales desencadenantes de riadas}

El Xúquer presenta en la Ribera características que han propiciado endémicas inundaciones. Rasgos inmutables favorecedores de los desbordamientos son el gran tamaño de la cuenca que aboca sus aguas en la zona, la escasa pendiente del terreno, así como la confluencia de importantes tributarios entre Alberic y Algemesí. Peculiaridades geográficas que - a diferencia de las anteriores- no han cesado de evolucionar son las modificaciones en la morfología del llano de inundación y las irregularidades pluviométricas.

\subsubsection{La confluencia de importantes tributarios del Xúquer}

Se trata de un factor geográfico subrayado por el ingeniero Bosch Julià a mitad del XIX y recordado por los geógrafos actuales. El primero ya dejó publicado, en 1866, que: «en el corto trayecto del Júcar comprendido entre las inmediaciones de Sumacárcel y la parte baja de la jurisdicción de Alcira, en tiempos lluviosos se acumulan las aguas del Escalona, del Sellent, del Montesa, del Albaida, del río y barranco de Barcheta, de los barrancos de Aguas-vivas, de la Casella y de la Murta, del río de los Ojos y de la rambla de Algemesi» ${ }^{27} \mathrm{La}$ trascendencia de este hecho se acrecentaba cuando los principales afluentes bajaban -simultáneamente- llenos a rebosar de agua, provocando el retroceso de la corriente del Xúquer. En 1864, «el desastre fue mayor por la coincidencia de la llegada a la parte inferior [de] la avenida producida por las lluvias de fin de octubre en el Júcar y Cabriel con las avenidas de todos los afluentes; [...] en la última inundación

25. J. F. MATEU BEl LÉs: «Cambios seculares de la agradación aluvial y de la meandrización en la Ribera Aita del Xúquet», Saitabi, XLII, 1992, págs. 183-205.

26. Artículos de diversos miembros del departamento de Geografia de la Universidad de Valencia.

27. BOSCH JULıA: op. cil., pág. 55. 
la rambla causó un remanso tan grande, que se notaba en el Júcar una corriente inversa que subía hasta Alcira» ${ }^{28}$ También en octubre de 1779 , la sincronía de las crecidas del Xúquer y Albaida provocó una riada muy grave. ${ }^{29}$

\subsubsection{Las anomalías pluviométricas}

Butzer, Mateu i Miralles han subrayado la relevancia de las anomalías climáticas como componentes explicativos de las peores inundaciones. Llegan a esta conclusión a partir de datos como la coincidencia cronológica entre muchos desbordamientos del Xúquer y las riadas en la cuenca baja del Turia, la simultaneidad de las inundaciones más graves con inviernos fríos y nevados, o bien el inusual régimen pluviométrico de los años en que se produjeron múltiples desbordamientos. ${ }^{30}$

\subsubsection{La sobreelevación del lecho del Xúquer}

Un importante factor desencadenante de las inundaciones (diagnosticado por P. Racsas y V. Vincensi en 1635) es la progresiva sobreelevación del lecho del río, que confiere progresiva inestabilidad al llano de inundación. Joan Mateu ha recogido, explicado y desarrollado las ideas de estos hidraulistas. El jesuita Racsas afirmó que la escasa pendiente del Xúquer en la Ribera propiciaba una fuerte sedimentación, de manera que «así la madre del río como las riberas se van levantando», lo que (unido a las circunstancias que el río circulara por cotas más altas que otros puntos del llano de inundación y que el territorio fuese muy plano) provocaba que «aun las pequeñas inundaciones se extienden mucho, [...] y así las aguas escapadas de las riberas no pueden volver a ellas y es fuerza que queden detenidas en los campos muchos días, de que sucede ahogarse los sembrados y crecer los depósitos y enterrarse poco a poco las moreras». ${ }^{31}$ Vincensi coincidía con Racsas, en señalar como causas naturales relevantes de las inundaciones que sufría la Ribera «las vueltas que hace el río antes de llegar a las Villas de Alcira y Carcagente, [...] la angostura del río, [...] el depósito que deja el río en sus avenidas [... así como] el estar bajas las riberas y orillas del río en algunas

28. J. Gómez ORTEGia et alii: Estudio de las inundaciones del Jucar por los ingenieros de caminos... Valencia, Confederación Hidrográfica del Xúquer (manuscrito de 1866), 1988, págs. 138 y 210 . Esta misma circunstancia se produjo en Algemesí en 1589, cuando «no poguent el río Sec abocar son aigua en el Xúquer, el regolf feu augmentar-lo de manera que rebassà las motes, eixint-se' n pels camps i el pohlat» (I. A. Domingo i Borràs: «Les nostres riuades. Perquè a hores d'ara?», Berca, 19, 1983, págs. 18-20).

29. La confluencia de afluentes como factor causal de los desbordamientos en la Ribera también fue señalada por LLANSOL en 1797: «todas las aguas de los montes de Albaida [...] y de Almansa [...] se vienen finalmente a unir al Xúcar. [...] Las aguas que llegan del mediodía, de Aguas Vivas y Albaida, encuentran con esta columna de las del Xúcar al puente de Alcira y se empantanan [o...] le hace caminar con un movimiento retrógrado)» (Topografía médica general..., págs. 105-106).

30. Como 1589-90 (K. W Butzer, I. MiRAlles i J. MATEu: «Las crecidas medievales del río Júcar según el registro geo-arqueológico de Alzira», Cuadernos de Geografía, n 32-33, 1983, pág. 330).

31. Cit. J. F. MATEu BelLés: «La ciència ì la tècnica davant les revingudes del Xúquer (1635-1905): Notes preliminars...», Cuadernos de Geografia, n³2-33, 1983, pág. 248. 
partes» ${ }^{32}$ Bosch Julià reiteró estas ideas, recalcando que el Xúquer tiende a sobreelevarse en ciertos lugares: «la masa de materiales que el Júcar y sus afluentes depositan constantemente en la Ribera favorece las inundaciones, levantando el lecho del río». ${ }^{33}$

\subsubsection{El efecto tapón de la confluencia del Magre en el Xúquer}

Los trabajos de Joan Mateu poseen dos méritos principales. Por un lado rescatar y divulgar las ideas de estos precursores. Por otra parte, recalcar que se trata de un proceso de sedimentación dinámica -todavía en marcha- que hay que relacionar con el efecto agravante provocado por cambios en la confluencia del Magre en el Xúquer:

Durante los siglos XVı y XVil el río Magro, depositó aluviones groseros de 3 a $4 \mathrm{~m}$ de potencia en su lecho y progradó un amplio abanico aluvial de limos y arenas en su confluencia con el Júcar. [...] El avance aguas abajo del abanico estranguló aún más la Ribera Alta, favoreciendo un activo aluvionamiento en los meandros y llano de inundación convexo situado entre Alberic y Alzira. [...] Al estimular el aluvionamiento de la Ribera Alta, el abanico del Magro creó un ambiente altamente susceptible a los daños producidos por las avenidas, hecho que puede relacionarse con el mayor número de inundaciones catastróficas con posterioridad a $1740 .^{34}$

El cuello de botella del Magre frenaba las aguas que bajaban por el Xúquer ${ }^{35}$ y propiciaba una intensa sedimentación de los materiales que arrastraban las aguas. De esta manera, iba configurándose «una llanura de inundación cada vez más inestable y propensa a respuestas de gran variabilidad ante lluvias extremas ${ }^{36}$

\subsection{Factores antrópicos agravantes de las riadas}

Acabamos de exponer como la baja pendiente - así como la entrada de las corrientes del Albaida y el Magre- hacía que el Xúquer perdiera velocidad, siendo incapaz de arrastrar hasta el mar los sedimentos que transportaba. En lugar de originar un delta - como otros ríos-, iba transformando la comarca mediante un aluvionamento muy desigual, según zonas. Además, diversos factores antrópicos intensificaban este proceso natural, agravando lo que hubieran sido las riadas estrictamente naturales. Entre éstos últimos cabe destacar las infraestructuras hidráulica o de transporte (azudes, acequias, puentes y caminos), así como la deforestación de la cuenca del Xúquer (que favorecía la erosión y arrastre de sedimentos).

De todos los elementos citados, el más polémico fueron los azudes donde nacían las acequias. Los habitantes de la Ribera Alta vieron -al final del XV y primera mitad del quinientos - como se construían azudes en la Ribera Baixa y como se agravaban

32. Cit. MATEU BelLÉs: art. cit., pág. 247.

33. BOSCH JULIA: Memoria..., pág. 84.

34. BUTZER-MATEU-MiRALLES: «Aluvionamiento medieval...», pág. 329.

35. Así se explica el remanso de la corriente que percibían los habitantes de Alzira y Algemesí, que diversas obras públicas agravarían con posterioridad.

36. BUTZER-MAtEU-Miralles: art. cit., pág. 330. 
los efectos de las riadas, de manera que no les resultó dificil relacionar ambos hechos. Según F. Fogués, durante la inundación de 1559 ya se alzaron voces culpando a los azudes de Cullera y Sueca de los desastres producidos por las aguas del Xúquer en la zona de Alzira y Carcaixent. ${ }^{37}$ Las dramáticas riadas de 1571 y 1632 avivaron la polémica. El dictamen de reputados hidraulistas corroboró lo que ya venían clamando los vecinos de las áreas más afectadas. ${ }^{38}$ Vincensi concluía que «el remedio general [...] es quitar todas las azudes y presas»». Racsas llegaba a la misma conclusión, aunque (consciente de la importancia del regadío en la zona) postulaba eliminar las presas de derivación, pero manteniendo el riego a base de captar los caudales del Xúquer en el punto que fuera necesario -aguas arriba-- a fin que Sueca, Cullera, Llaurí y Riola pudieran conservar los perímetros irrigados que habían creado ${ }^{39}$ Estas propuestas no llegaron a ejecutarse nunca. El tema se dio por resuelto con una concordia entre los pueblos implicados: consistía en obligar a que los azudes tuviesen unos portillos con capacidad suficiente para dejar pasar la corriente del Xúquer, que estarían abiertos durante los meses con mayor peligro de riada y sólo se cerrarían en la época en que el riego era más necesario. ${ }^{40}$

Otras infraestructuras contribuían a agravar las riadas. F. Llansol señalaba, en 1797, que las carreteras entorpecían el drenaje de las aguas y recalcaba como los diques de defensa que habían levantado algunos municipios agravaban los problemas que sufrían otros pueblos:

$\mathrm{Al}$ paso que se han puesto obstáculos al curso del río, se aumenta el peligro. El camino nuevo a Valencia es un malecón que impide mucho el derrame de las aguas, quando sale del cauce, y las hace repechar contra Alcira. [...] En Carcaixent, también le impiden la entrada con otro malecón y le obligan a tomar el rumbo para esta villa. En Alcira, en el mismo puente de San Gregorio, $[\ldots]$ se hicieron dos presas o azudes para conducir el agua al molino, y los arcos, de la detención de las aguas y la arena de las avenidas, están ya sobre 15 palmos enterrados, achicándose de este modo los ojos. ${ }^{41}$

37. Fogués JuAN: Historia de Carcagente..., pág. 150.

38. MATEU Bellés: «La ciència i la tècnica....», pág. 245.

39. MATEU BELLÉS: art. cit., pág. 248.

40. MATEu BelLés: art. cit, pág. 246. La trascripción del pleito de los azudes de la Ríbera Baixa y la concordia de 1635, con la que se resolvió la cuestión, puede verse en PILES-GINER: Historia de Cullera, págs. 366-367 y 396-399. Dos siglos después, GÓMEz ORTEGA minimizaba la problemática de los azudes: «su cauce se presenta [...] suficientemente hondo, para que cuando llegue a desbordar no se conozca, apenas, en la superficie la influencia de las presas, de modo que en avenidas ordinarias todos los perjuicios por efecto de él se reducen a hacer que se inunden a derecha e izquierda algunos, aunque no muchos, más territorios que si no las hubiera, mientras que en las extraordinarias [...] la influencia es nula. Sólo, pues, a la proximidad de poblaciones emplazadas en puntos bajos de las orillas y en donde una pequeña sobreelevación en el agua tenga ya influencia muy marcada, es donde debe proscribirse la construcción de las presas» (Estudio de las inundaciones..., págs. 159-160).

41. LlANSOL: Topografia médica general..., págs. 107-108. La deforestación de la cuenca y los diques de defensa fueron otras actuaciones antrópicas que modificaban el régimen natural del Xúquer durante las crecidas. 


\subsection{El perspicaz diagnóstico de Racsas sobre las riadas del Xúquer (1635)}

La diagnosis realizada por Paulus Racsas sobre las causas que ocasionaban las inundaciones del Xúquer sorprende por su gran lucidez, ya que reconoce el impacto de factores difíciles de percibir con los rudimentarios medios disponibles en aquella época. Racsas señaló como principales agentes causales los siguientes. En primer lugar, la sedimentación acumulativa de aluviones: «cantidad de aguas que bajando de las montañas muy cargadas de tierra $[\ldots]$ la van dejando en la tierra llana, $[\ldots]$ con que así la madre del río como las riberas se van levantando y enterrándose los árboles y las casas, como se ve en Carcagente, Alzira y Albalat». Otro factor era la «poca pendiente del río y mansedumbre de su corriente, después que bajando de los montes comienza a caminar por los llanos, con que no tiene fuerza para llevarse los depósitos que trae». También consideraba que influía la escasa pendiente del territorio, que hacía que los desbordamientos afectaran a una gran superfície. Igualmente, cita la «estructura del albeo o madre del río», así como el hecho de estar «las riberas embarrancadas con cañaverales y matorrales». En último lugar, alude a los azudes «que desde Alcira a Cullera [hay] en el río, donde es forzoso regolfe el agua». ${ }^{42}$

\section{LAS CONSECUENCIAS DE LAS INUNDACIONES DEL XÚQUER}

Nuestros conocimientos sobre los cambios geomorfológicos experimentados en el llano de inundación, las obras de defensa ejecutadas para paliar la furia de las aguas o las causas que originaron los desbordamientos del Xúquer comienzan a resultar bastante satisfactorios. Por el contrario, los efectos económicos y sociales ocasionados por las riadas del Xúquer durante los siglos XV-XIX siguen siendo -en buena medida- una incógnita todavía por resolver, que sigue desafiando a los investigadores.

\subsection{La trascendencia de la perspectiva de análisis adoptada}

Una premisa básica que debería guiar el análisis es que los desbordamientos del Xúquer no han de tomarse exclusivamente -de manera limitadora-como pulsaciones espasmódicas de carácter extraordinario. Hay que contemplarlas como un fenómeno estructural, endémico, constituido por un conjunto muy numeroso de desbordamientos, que se repetían con una asiduidad bastante mayor de lo que se supone. No sólo se produjeron la decena de inundaciones extremas más conocidas: 1473, 1517, 1571, $1589,1632,1776,1779,1802,1805$ y 1864 . El catálogo tampoco resulta completo añadiendo otras cincuenta riadas extraordinarias bastante citadas. Todavía es necesario añadir infinidad de crecidas ordinarias, que culminaban en desbordamientos de baja energía, episodios durante los cuales las aguas inundaban parte del territorio agrícola y depositaban fértiles sedimentos en los campos. ${ }^{43}$ Hay que ser conscientes que al

42. Cit. MATEu Brillés: «La ciència i la tècnica...», pág. 248.

43. Los documentos -lógicamente-- casi nunca se ocupan de este tipo de avenidas fluviales, ya que no ocasionaban victimas ni pérdidas dignas de mención. En general, sólo se alude a las inundaciones ordinarias 
tratar de las riadas del Xúquer nos estamos refiriendo a una extensa serie de episodios muy heterogéneos, que ocasionaban efectos bien distintos. Nadie discute que hay que estudiar de manera preferente las pocas riadas de gran magnitud que produjeron graves daños. ${ }^{44}$ Pero nada autoriza a negligir el gran número de beneficiosas crecidas ordinarias, durante las que el río se limitaba a aportar limos fecundantes.

Resulta fundamental tener presente que los documentos que tratan de las inundaciones del Xúquer no constituyen una muestra aleatoria, sino muy sesgada. Los desperfectos causados por las aguas embravecidas en las obras públicas siempre fueron muy llamativos y su reparación ha dejado un abundante rastro documental. Por el contrario, cualquier tipo de beneficio reportado por los desbordamientos a los campos resulta -injustificadamente-ignorado. Durante las numerosísimas avenidas ordinarias, la corriente turbia, cargada de nutrientes, superaba los márgenes del río e inundaba el llano sin causar desperfectos dignos de mención. En consecuencia, estos episodios nunca merecieron el interés de los cronistas y han escapado a las indagaciones de los pocos historiadores que se han ocupado de estudiar las riadas del Xúquer. ${ }^{45}$ Ahora bien, esta circunstancia no implica aceptar que los desbordamientos moderados fuesen hechos irrelevantes.

A la hora de precisar los efectos de las riadas del Xúquer, resulta radicalmente distinto efectuar un análisis puntual de un acontecimiento concreto que realizar un estudio de larga duración que incluya al total de crecidas producidas en el conjunto de la comarca. Si nos fijamos en una avenida de aguas, a buen seguro que el esfuerzo investigador se dirigirá hacia alguna inundación extraordinaria o extrema que, precisamente por los notables efectos destructores ocasionados (víctimas, desplome de edificios, cuantiosas pérdidas económicas), ha dejado prolijas referencias documentales que permiten redactar brillantes trabajos. Por el contrario, si nos inclinamos por realizar un estudio de larga duración que contemple al total de desbordamientos acaecidos en la Ribera, el resultado será de signo muy distinto. En este segundo caso, los llamativos efectos devastadores de unas pocas riadas extraordinarias -que nadie discute- quedan eclipsados entre las consecuencias positivas reportadas a largo plazo por un conjunto muy numeroso de desbordamientos ordinarios, hasta el punto de obtener un balance seguramente más beneficioso que negativo. ${ }^{46}$

que destacaron por su larga duración, su reiteración o la circunstancia de producirse en un año con riada extraordinaria o extrema. Por ejemplo, sabemos que durante 1590 se registraron más de 22 riadas, el doctor F. Llansol recuerda como en 1784 se produjeron al menos 9 inundaciones, Fogués indica que las aguas del Xúquer se desbordaron varias veces en 1795, etc.

44. Aunque tampoco podemos olvidar que las riadas extraordinarias y extremas dejaron gruesas capas de sedimentos, beneficiosos desde el punto de mira edafológico, en extensas zonas de la Ribera.

45. Sobre todo aquellos que han escrito sus trabajos durante el siglo XX, cuando la posibilidad de aportar abonos químicos a los campos ya era ilimitada, de manera que resulta dificil captar la trascendencia fecundante que tuvieron crecidas e inundaciones en las economías agrarias tradicionales, en ta que el principal problema consistía en reponer a los campos los nutrientes absorbidos por las cosechas.

46. M. Bosch Julià informa que incluso en una riada extrema tan catastrófica como la de 1864 , hubo zonas de la Ribera, como el término de Sollana, en las que «las aguas se extienden por la jurisdicción con lentitud, sin que las corrientes causen daños» (Memoria..., pág. 359). 
A nadie se le ocurre sostener que las lluvias sean globalmente perjudiciales, por muy grandes que sean los daños ocasionados - de tanto en tanto - por granizadas y temporales. A todos resulta obvio que son infinitamente mayores los beneficios reportados por las Iluvias ordinarias, que vivifican la vegetación, sazonan los campos, recargan los acuíferos y engruesan los ríos. Idénticas razones obligan a modificar la perspectiva desde la que contemplar las avenidas de aguas de los ríos mediterráneos. Una mínima parte del total de crecidas de Xúquer fueron inundaciones extraordinarias o extremas, episodios tan dramáticos y nocivos como bien conocidos; por el contrario, una gran mayoría fueron avenidas fluviales y desbordamientos moderados que reportaban a las comunidades rurales ribereñas unos beneficios tan grandes como ignorados.

\subsection{Las conocidas repercusiones negativas de las riadas extraordinarias y extremas}

La mayoría de daños económicos provocados por el agua y el fango de las inundaciones se manifestaban de forma inmediata al desbordamiento de las aguas. Destacan los desperfectos ocasionados en diversas infraestructuras (puentes, caminos y red de acequias), edificios y campos, así como las pérdidas de ganado y la destrucción de cosechas.

\subsubsection{Los diversos perjuicios económicos}

\section{- Daños en las infraestructuras}

Acequias, puentes y molinos eran construcciones muy expuestas al efecto destructor de la corriente. ${ }^{47}$ Las infraestructuras hidráulicas resultaban especialmente vulnerables a las riadas, al constituir obstáculos que se oponían al flujo de las aguas. Como la superficie regada se multiplicó en la Ribera desde mitad del cuatrocientos hasta mediados del siglo XIX, ${ }^{48}$ los daños ocasionados por las riadas fueron cada vez mayores. Los azudes y los tramos iniciales de las acequias fluviales resultaban destrozados durante las avenidas de aguas más fuertes, mientras que el fango dejado por la corriente obstruía los canales de riego. A. Piles relata como el azud de Cullera resultó arrasado en las riadas de 1643, 1686, 1779, V. Pelufo describe que la avenida de 1779 rompió los cajeros del brazal de Alzira y V. Ribes expone como la inundación de 1786 provocó diversas roturas en la acequia Comuna de l'Ènova. Yo mismo he constatado los estragos que provocaban las aguas del Xúquer y el Albaida en las acequias de

47. Los desperfectos en molinos aparecen expresados reiteradamente entre los daños suscitados por las crecidas, ya que la ubicación de parte de ellos en la orilla de ríos y barrancos los convertía en edificaciones muy expuestas a la furia de las aguas. Así, el dueño del molino de La Volta de Castelló resultó muy perjudicado en la riada del 4 de octubre de 1779, ya que las aguas se llevaron 60 cahíces de arroz allí guardados y dejaron el edificio destrozado (V. RIBES IBORRA: Secrets del Castello set-centista, Valencia, Cooperativa del Camp de Vilanova de Castelló, 1987, págs. 26 y 92).

48. Todas las acequias de la Ribera Baixa, así como Escalona y Carcaixent, se crearon durante la etapa estudiada y la Real del Xúquer experimentó una importantísima ampliación al final del siglo XVIII (PERIS AlBENTOSA: La terra de l'arròs i les moreres..., págs. 45-78). 
Escalona ${ }^{49} \mathrm{y}$ Real de Alzira. El azud de la acequia Real (construido dentro del lecho del río, junto a Antella) era el primer elemento afectado durante las crecidas del Xúquer. Cualquier pequeña rotura, agrandada por la fuerza de las aguas y el impacto de los troncos que bajaban flotando por el río, amenazaba al conjunto de la presa. Por eso, se realizaban con tota celeridad reparaciones urgentes, como las de 1740 , en las que trabajaron grupos de 20 hombres durante 41 días. Con diversos tipos de vigas ('cavalls', 'traves' y estacas) se formaba un encajonado, firmemente anclado en el lecho del río, que después se rellenaba con grandes piedras. El coste de estos arreglos pocas veces bajaba de 5.000 libras $^{50}$ y en 1864 fue necesario gastar 2.816.000 reales (S. Calatayud calcula que los deterioros producidos por esta riada extrema en el conjunto de sistemas hidráulicos de la Ribera ascendió a 13 millones de reales). ${ }^{51}$ Además, la corriente de las crecidas ordinarias ocasionaba diversos taponamientos - 'embarrerades'-y derrumbes - 'solsides' - en las acequias, que había que resolver con urgencia. ${ }^{52} \mathrm{Al}$ coste que requería reparar estos destrozos, hay que añadir las pérdidas agrícolas ocasionadas durante el tiempo que tardaba en volver a circular agua por los canales de riego, lapso a menudo superior a 30 días.

La mayoría de molinos hidráulicos eran edificios muy expuestos al efecto destructor de la corriente. ${ }^{53}$ Especialmente graves eran los desperfectos sufridos por los ubicados en las márgenes del Xúquer (como el Molí Reial que existía junto al puente de Sant Gregori en Alzira), ${ }^{54}$ motivo por el que los numerosos molinos fluviales exis-

49. Peris Albentosa: La gestió hidràulica en la sèquia d'Escalona (1605-1993), Alcàntera, Ajuntament de Castelló de la Ribera, 2003, passim.

50. Era, después de la limpieza anual de los canales, el segundo gasto más importante de la Acequia.

51. S. CALATAYUd Giner: «La revinguda de 1864».

52 «[...] per rahó de la gran creixcuda del riu, y avia una gran parada de rames, troços de tronchs, brosa, corfes de pi y altres enmundicies al pont de la Orta de Antella y la boca dels Alcavons, de tal manera que tota l'aygua saltava per les vores»; "pujà al brasal de la Vila a fer traure unes solsides [...] per rahó de la vinguda del riu, y fer tapar quatre trenchs grans que y avia en dit brasal, defront los Alvajals, per rahó de dita crexcuda del riu» (Archivo Municipal de Alzira, 0694/8, f. 30 y $116 \mathrm{v}$; véase T. PERIS ALBENTOSA: Regadio, producción y poder en la Ribera del Xúquer (la Acequia Real de Alzira, 1258-I847). Valencia, COPUT i Confederación Hidrográfica del Júcar, 1992, págs. 101-116 y 227-237).

53. Así, la corriente del 4 de octubre de 1779 destrozó los molinos de Moleny y de la Volta, en Castelló de la Ribera (RIBEs: Secrets..., págs. 26 y 92; MARTí Soro: Historia de Villanueva..., págs. 170, 185-187 y 509). En 1860 había 70 molinos funcionando en las acequias de la Ribera, que eran tasados en 144 millones de reales, mientras que el valor de las acequias se estimaba en más de 400 millones de reales (A. SANCHO i S. MONLEÓN: Dictamen facultativo..., pág. 31). Véase PERIS AlbeNTOSA: «Aigua i molins en un macrosistema fluvial valencià. La molinería a la Ribera del Xúquer, segles XIII-XIX», en GLICK, GuINOT y MARTínez (eds.): Els molins hidràulics valencians, Valencia, Alfons el Magnànim, 2000, págs. 273-388).

54. Su arrendamiento proporcionaba al municipio 1.260 libras en 1768 , equivalente al $11 \%$ de los ingresos del ayuntaniento de Alzira. La riada de 1805 dejó destrozado este molino y a los alzireños tan escarmentados (acumulaba sedimentos junto al puente de Sant Gregori, cegando sus arcos), que se dirigieron a los oficiales reales haciéndoles saber el «clamor [existente...] para derribar el azud de piedra que conducía las aguas al molino inutilizado. [...] Están tan animosos que, por tandas y sin coste, quitarán la piedra del azud» (Archivo Municipal de Alzira, Río Xúquer, $\mathrm{n}^{\circ}$ 6). 
tentes en tiempos medievales fueron sustituidos por otros impulsados por las aguas de acequias, conforme la red de canales fue ampliándose.

Los puentes eran otras infraestructuras susceptibles de ser afectadas por las riadas. Benlloch comentaba, en 1756, que las modificaciones del lecho del río y la rotura de puentes eran los principales destrozos que el Magre ocasionaba en el marquesat de Llombai. ${ }^{55}$ Los puentes más afectados por las crecidas del Xúquer eran los de Alzira y Cullera. El existente en el río Dels Ulls, para que el camino de Valencia a Xàtiva atravesara este afluente del Xúquer, quedó destruido durante la inundación de 1709. Los dos grandes puentes de Alzira resultaron afectados por las fuertes riadas de principio del siglo XIX (en especial el de Sant Agustí en 1805 y 1814). La desaparición de los puentes de barcas de Cullera resultaba habitual en las avenidas más graves, reiterándose noticias en este sentido desde las décadas de $1770-80$ y en las riadas de 1805,1806 y $1808 .{ }^{56}$

También los caminos sufrían la furia del Xúquer, en especial por los derrumbes que se producían en la parte cóncava de ciertos meandros, como explica Joan Mateu. ${ }^{57}$ V. Pelufo indica que la riada del 6 de octubre de 1783 modificó el meandro que había entre el puente de Sant Gregori de Alzira y la partida de la Almúnia, «de manera que quedó inutilizado el camino del Toro y Alberique, que se tuvo que trasladar al del Puchol». ${ }^{58}$ Una de las iniciativas impulsadas en Alzira a raíz de la inundación del 1806 consistió en construir un grueso muro para defender el camino de Valencia, amenazado por uno de los derrumbes de los cajeros del río..$^{59}$ Los caminos de la Ribera Baixa que discurrían demasiado cercanos al Xúquer también resultaron afectados durante la

55. F. BENLLOCH: Descripción del Marquesado de Lombay, su antigüedad, principio y señorio... 1756 (reed. Valencia, Ajuntament Llombai 1975), pág. 30.

56. El efecto destructor de las inundaciones era-precisamente- la causa principal que explica la abundancia de barcas para atravesar el Xúquer, así como de la escasez de puentes hasta comienzo del siglo XX (PERIS AlBEnTOSA: La terra de l'arròs i les moreres..., págs. 188-190).

57. «Por la margen izquierda del Xúquer, discurre un camino que, ya en tiempos islámicos, unía Alberic con Alzira pasando por Benimuslem. Las divagaciones del cauce han cortado al menos por tres puntos el primitivo trazado (Benimuslem, Racó de l'Alborgí y las cercanías de Alzira). Otro tanto sucede en la margen derecha: también la erosión fluvial ha cortado puntualmente el antiguo camino que unia Alzira con Cárcer [...]. A pesar de algunos estrangulamientos del cauce, el río ha incrementado la sinuosidad desde los tiempos islámicos. La anchura de la franja de meandrización se ha ampliado porque los dos antiguos caminos que discurrían próximos al cauce en ambas márgenes han sido puntualmente erosionados por los bordes externos de algunos meandros» (MATEU BELLÉS: «Cambios seculares de la agradación aluvial...», págs. 199-200).

58. PELUFO: «Inundaciones, terremotos y pestes...», publicado en la revista Xúcar entre octubre de 1935 y marzo de 1936, reeditado recientemente en V. Pelufo y J. M. PARra: Páginas de la historia de Alzira, Alzira (ed. A. LAIRÓN y Falla Camí Nou), 1987.

59. «[...] paredón proyectado a fin de que las aguas, en su tránsito, no destruyan e inutilicen el Camino Real que guía desde esta villa [Alzira] a esa capital [Valencia]» (Archivo Municipal de Alzira, Río Xúquer, $\left.n^{\circ} 6\right)$. 
primera mitad del siglo XIX, como podemos constatar junto a Albalat ${ }^{60}$ y Bosch Julià informa que ocurrió cerca de de Sueca. ${ }^{61}$

- Hundimiento de edificios

Las casas más viejas, menos sólidas (así como las ubicadas allí donde incidía con más fuerza la corriente) sufrían en mayor medida los efectos de las riadas, hasta el punto de derrumbarse de forma masiva durante los principales desbordamientos. V. Pelufo informa que durante la gravísima riada de 1473 quedaron destruidas más de 900 casas en el extenso término que Alzira tenía en aquella época. Este mismo autor explica como la inundación del 27 de septiembre del 1517 «derribó 31 casas en Sumacárcel, la mitad de Gabarda, todo Alcocer, en donde sólo quedó en pie la Iglesia y siete casas más. En el arrabal de Alcira se hundieron muchas, y hubo que lamentar algunas víctimas». Otras fuentes informan que las aguas del Magre afectaron duramente a Carlet (en especial el raval mudéjar de Maçalet), donde la corriente «arrebató cien casas». ${ }^{62}$ F. Fogués, por su parte, indica que las riadas de 1683 «causaron enormes destrozos en Sueca». La gran avenida del 4-5 de octubre de 1779 ocasionó la destrucción de Alcosser y Senyera, el hundimiento de muchas casas en los arrabales de Alzira y notables destrozos en Carcaixent. Por último, la avenida del 14-16 de noviembre de 1805 afectó de forma muy grave a buena parte de la Ribera: el agua alcanzó en Alzira una altura comprendida entre 2,1 y $2,9 \mathrm{~m}$. -según la zona- derrumbando 61 casas y obligando a apuntalar otras 200 para impedir su inminente ruina ${ }^{63}$ (en Carcaixent también se hundieron muchas viviendas). El efecto destructor se multiplicaba cuando la corriente arrastraba los troncos de pino amontonados en las orillas del río, ya que éstos golpeaban las paredes de las casas hasta ocasionar roturas, de manera que al quebranto económico derivado de la pérdida de la madera hay que añadir los destrozos ocasionados en los edificios.

\section{- Pérdidas ganaderas}

Durante las principales inundaciones $(1517,1571,1632,1779$, etc.), muchos animales murieron ahogados, desgracia especialmente cuantiosa cuando la crecida cogía por sorpresa a los ribereños. Las noticias más antiguas apenas contienen alusiones lacónicas, como que la corriente arrastró ganados. En otros casos, se añaden más detalles: «destrozó Señera, muertes de [...] animales mayores treinta y cuatro [...]. En Carcagente les pilló desprevenidos [...] y murieron muchos caballos. Alcira por lo

60. Gómez ORTÉia: Estudio de las imundaciones..., plano $\mathrm{n}^{\circ} 10$.

61. «Tres veces en 30 años ha tenido que variarse la dirección de este camino por el ensanchamiento del río» (BOSCH Julià: Memoria ..., pág. 355).

62. BALlester BROCETA: Historia de la villa de Algemesi en la provincia de Valencia, Algemesí, Imprenta J. B. Juan, 1958 (reed. Juan B. Juan, Algemesí 1988), pág. 73; V. VALLÉs BORRẢs: «Germania i senyoriu; la Baronia de Carlet», Al-gezira, III, 1987, pág. 139.

63. Gómez Ortega: Esiudio de las inundaciones del Júcar.... pág. 87; Peris Albentosa: L'escenari i els protagonistes..., págs. 103-104. 
mismo". ${ }^{64}$ Hay que esperar a mitad del siglo XIX para disponer de cuantificaciones minuciosas. Así, durante la riada de 1864 se ahogaron en Alzira « 368 caballerías mayores, 293 menores, 39 cabezas de ganado vacuno, 133 de ganado de cerda y 9.882 aves de corral» y en Carcaixent perecieron 250 caballerías y 200 cerdos ${ }^{65}$

\section{- Destrozos en los campos}

Las aguas desbordadas ocasionaban diversos deterioros en las huertas. Unos, resultaban independientes del momento del calendario agrícola en que se producía la riada. El más nocivo era el arrastre de la capa edáfica por la corriente, con la subsiguiente ruina de las huertas contiguas al lecho fluvial en lugares de alta capacidad erosiva (entre Sumacàrcer y Alberic) ${ }^{66}$ Costosos de reparar eran los depósitos de sedimentos perjudiciales -arena y grava- que la corriente dejaba cerca del río. Los perjuicios ocasionados en el arbolado -integrado sobre todo por moreras- no fue un capítulo oneroso, excepto en las riada extremas ocurridas al final del antiguo régimen. El depósito de sedimentos de grueso calibre en los campos (perjudiciales desde el punto de vista edafológico) adquirió importancia a partir de mitad del setecientos, hecho que hay que relacionar con la deforestación de la cuenca baja del Xúquer. Mientras la cubierta forestal fue aceptable, la corriente se limitaba a arrastrar parte del mantillo de las montañas, un material que mejoraba los suelos del llano de inundación. Las roturaciones del XVIII y la tala abusiva-ocasionada por el carboneo- hicieron que la potencia erosiva de las lluvias se multiplicara, hasta el extremo de arrastrar aluviones cada vez más groseros y «dejar la roca que constituye el subsuelo completamente descarnada». ${ }^{67}$ En la reseña de la riada de 1776, se alude de pasada a los «destrozos causados en [...] campos $\gg .^{6.8}$ Respecto a la inundación de 1802 , ya se informa como en el término alzireño «se esterilizaron los más preciosos terrenos de las huertas [...] de más de ocho mil hanegadas de tierra en ambas márgenes del río, con una pérdida incalculable [...], sigue también en la baxa enormísima del precio de las tierras que se han inutilizado por la inmensa multitud de arena que el Xúcar ha superpuesto en ellas, de suerte que $[\ldots]$ ha perdido el término en frutos y valores de terrenos [...] más de seiscientos mil pesos $\gg{ }^{69} \mathrm{Y}$ la avenida de aguas del 14-16 de noviembre de 1805 dejó en los campos de Algemesí, «particularmente en las partidas de Fentina y Gégena, [...] tan grandes

64. Informe conservado en el archivo parroquial de Càrcer sobre la riada del 1779, citado por GómEZ ORTEGA: Estudio de las inundaciones..., págs. 82-83.

65. Memoria sobre la intundación del Júcar..., pág. 344 (para el conjunto de la comarca ver págs. 315360 ).

66. S. BODí i CONGRòs explicaba que durante la gran riada de 1864, la «violencia de las aguas arrebató de los montes y huertas de los pueblos situados en las alturas [antes de llegar a la Ribera] lo mejor de sus tierras» (El clima de la Ribera en el siglo XIX, Carcaixent, Ajuntament, 1986, pág. 75).

67. BosCh Julià: Memoria ..., págs. 220-221.

68. PELUFO: «Inundaciones, terremotos y pestes...».

69. Archivo Municipal de Alzira, Río Xúquer, $n^{\circ} 15$. 
masas de arena, que no sólo borró los linderos de muchas fincas, si que en muchos puntos dejó grandes motas de tierra que aún subsisten». ${ }^{70}$

- Pérdida de cosechas

Otro tipo de daños provocados por las inundaciones - como la pérdida de cosechas- dependía más del momento en que se producía la riada que de las magnitudes físicas de la crecida. Una parte de los destrozos la ocasionaba la corriente, que tumbaba plantas y destruía frutos. Otra, correspondía a las aguas fangosas que quedaban encharcadas en los campos y mataban los cultivos. En ocasiones se veía «desaparecer las cosechas que tenían en la era, arrastradas al mar por las avenidas». ${ }^{7 !}$ Resulta fundamentar dilucidar si las aguas desbordadas encontraban los campos ocupados por cosechas básicas o - por el contrario- se producían durante temporadas menos peligrosas. Las peores riadas eran las de primavera y verano, cuando los principales cultivos estaban crecidos o a punto de cosecharse. Esta circunstancia explica que la inundación del 12 de mayo de 1775 ocasionara «graves daños en casas y cosechas» del término de Alzira. ${ }^{72}$ También, que la del 12 de marzo de 1802 originara en Alzira la pérdida de «todas las cosechas, lo que fue causa de que el hambre visitase muchos hogares». $\mathrm{O}$ que Cullera viera arruinada casi por completo sus arrozales durante el desbordamiento de 1808. En sentido contrario, los perjuicios ocasionados por las riadas a partir de mitad de octubre eran reducidos, puesto que la cosecha de arroz ya había sido recogida, como ocurrió en la inundación de 1864 («Si la crecida del Júcar hubiera sobrevenido a últimos de agosto o a primeros de setiembre arruina a los vecinos de Sueca y demás poblaciones que cifran su principal riqueza en el cultivo del arroz. Mas habiendo ocurrido en noviembre, los arrozales son las tierras que salieron mejor libradas $\rangle) .{ }^{73}$ Otros efectos nocivos consistían en el arrastre del estiércol, la paja o los cereales. ${ }^{74}$

\section{- Alteración de la normalidad económica}

La actividad económica resultaba perturbada -en mayor o menor medida, durante más o menos tiempo- después de cada riada Los desbordamientos comenzaban por aislar a la población, efecto más palpable en caso de inundaciones largas. Durante 1590 , año en el cual se produjeron más de 22 avenidas, debió ser difícil y arriesgado circular

70. B. Ballester Broceta: Historia de la villa de Algemesi..., pág. 149.

71. J. B. Peyronet: Memoria sobre el proyecto de canal del rio Jicar, Valencia, Imprenta Ayoldi, 1860, pág. 15.

72. PELUFO: «Inundaciones, terremotos y pestes...».

73. Bosch JULIÀ: Memoria ..., pág. 236.

74. Fogués: Historia de Carcagente..., pág. 153. En cambio, otras avenidas se produjeron cuando no se esperaba coger una buena cosecha, como se concreta que ocurrió el año 1779 en Castelló de la Ribera, término en el cual los daños sólo se evaluaron en 3.418 libras, pérdidas escasas porque esta importante riada sólo pudo llevarse «lo poco que havía dexado el granizo» (RIBES IBORRA: Secrets..., págs. 220223; MARTi SORo: Historia de Villanueva ..., págs. 170, 185-187, y 509). Sabemos que la mayoría de riadas destructoras se producían entre mitad de septiembre y comienzos de noviembre (BOSCH JULiA: Menoria sobre la inundación..., págs. 132-133). 
por la Ribera. La incomunicación también se sufrió en febrero de 1627, durante los más de 20 días que duró esa avenida, o en 1672, cuando el Xúquer se desbordó 11 veces. Situaciones semejantes se reiteraron en $1684,1714,1744,1763$, etc. ${ }^{75} \mathrm{~V}$. I. Franco atribuye más responsabilidad en el abandono de diversos núcleos ubicados en la cuenca del Riu dels Ulls a las incomodidades provocadas por los desbordamientos del Xúquer que al paludismo que esgrimía Cavanilles. ${ }^{76}$

La anormalidad económica comenzaba por la falta de harina. ${ }^{77}$ Seguía manifestándose con la rotura del calendario agrícola durante los meses que estaban inoperantes las acequias o los campos permanecían con el agua encharcada. Las tierras quedaban momentáneamente incultas y faltaba el trabajo a los jornaleros. Esta pésima coyuntura obligaba a las autoridades a repartir alimentos entre los vecinos más necesitados, a fin de tranquilizar los ánimos, como fue necesario hacer en Alzira en 1684 o $1745 .^{78}$ Los efectos de la riada todavía se manifestaban meses después, cuando no había más remedio que rebajar los arrendamientos de tierras para poder encontrar cultivadores ${ }^{79}$ y las autoridades estatales accedían a rebajar impuestos para facilitar la vuelta a la normalidad de las comunidades rurales.

\section{- El ejemplo de los daños ocasionados por la grave riada de 1864}

La descripción de los daños provocados por la gran inundación de 1864 en Alzira, que realizó Bosch Julià, resume bien la magnitud del impacto que las crecidas extraordinarias:

Aunque el cauce del Júcar se presenta regularmente profundo y ancho en las inmediaciones de Alcira, no es con todo capaz de contener las aguas del río en las avenidas un poco

75. Durante estos episodios se produjeron escenas como las que E. Císcar describe en la granja de Benibaire en la segunda mitad del XVII, cuando «Benibayre y sus casas quedan inundadas durante varios días y solo pueden desplazarse en barca» (E. CíSCAR PALLARÉS: «Las 'granjas' del monasterio de la Validigna en los siglos XVı i XVII), Al-gezira, IX, 1996, págs. 145-176). Para hacernos una idea del drástico aislamiento que se padecía durante los desbordamientos, hay que tener presente que unas simples lluvias eran capaces de interrumpir el tránsito por el camino que unía Alzira con la Validigna, de manera que los carreteros habian de esperar al menos un par de días en el hostal de La Barraca a que las aguas menguaran y poder vadear el barranco de l'Estret.

76. Citado por V. Ribes IBORRA: La Ilustración marginada..., págs, 121 y 151.

77. La imposibilidad que funcionaran los molinos y los hornos después de las grandes inundaciones (cuando la leña y la harina estaban mojados) ocasionaba la carestía de pan. PELUFo señala que on la riada de 1763 faltó la harina en Alzira (art. cit.). Y ios documentos relativos a la gran riada de 1864 en Alzira indican que se padeció «falta de harina, por consecuencia de no funcionar los molinos», de manera que las autoridades municipales se encargaron de ordenar a los panaderos que amasaran pan («y como quiera que los hornos carecían de leña, se acordó el que se recorrieran todos ellos y se les indicase las casas particulares en donde se les proporcionaría este combustible»; A. M. A., Rio Xúquer, n 18).

78. Aunque después existía una demanda excepcional de mano de obra para reparar infraestructuras y dejar los campos en óptimas condiciones.

79. V. Giménez CHORNET comenta esta reacción en Alberic después de la inundación de 1797 (Desenvolupament capitalista en el sistema feudal. Alberic en l'antic règim, Valencia, Imprenta Llorens, 1994, pág. 203). 
fuertes, siendo bastante comunes las inundaciones de los campos, y no tan raras como sería de desear las de las partes bajas de la población [...]. Las cosechas de cereales, hortalizas, forrajes y naranja sufrieron bastante; [...] fueron destruidos por la corriente 160.000 vides y 48.657 árboles, entre naranjos y otros frutales, moreras, olivos y algarrobos. Pero la desolación de los campos no guarda proporción con las extraordinarias pérdidas que tuvieron lugar dentro de la villa en animales domésticos, frutos, mobiliario, objetos de comercio, etc. Cien casas quedaron destruidas, 331 medio hundidas, 203 con grandes deterioros, 50 amenazando ruina. Perecieron 368 caballerías mayores. [...] Doce desgraciados fueron víctimas de la inundación $[\ldots] .{ }^{80}$

\subsubsection{Los problemas ocasionados por modificaciones en el cauce del Xúquer}

El conjunto de desperfectos que acabamos de describir tenían en común el manifestarse de forma inmediata. Otras consecuencias negativas iban manifestándose a medio y largo plazo, destacando diversas cuestiones relacionadas con cambios del lecho del río, así como mutaciones relevantes en la estructura del poblamiento.

Las modificaciones del lecho del Xúquer obligaban a cambiar el emplazamiento de ciertos edificios que habían quedado -peligrosamente- a sus orillas, impulsaba a construir diques protectores y forzaba a modificar el trazado de las acequias o caminos demasiado expuestos al avance de algún meandro. Por último, originaba costosos pleitos con los pueblos vecinos por causa de los límites del término municipal, ya que el río hacía de mojón. Uno de los primeros casos conocidos fue motivado por la riada de 1604, que «abrió un nuevo cauce al Júcar en la partida de Lancia de Riola, por lo que los de Sueca se quedaron sin agua para el riego». ${ }^{81}$ Otro buen ejemplo lo constituye el traslado de la iglesia de Gabarda: el templo de Sant Antoni quedaba al borde del Xúquer y (al resultar cada vez más afectado por las riadas) sus parroquianos decidieron, en 1735, construir otra iglesia alli donde todavía no llegaban las aguas de las crecidas. 82

Las riadas más fuertes causaban cambios notables en el lecho del río. Uno de los puntos más inestables fue la desembocadura del Albaida en el Xúquer, donde estaba el poblado de la Paixarella. La inundación de 1517 lo destrozó; las avenidas de 1779 provocaron la apertura de un nuevo lecho, la riada de octubre de 1785 --al variar el trazado del Albaida- dejó al descubierto las casas abandonadas de la Paixarella y la de 1790 completó la colmatación del antiguo meandro abandonado. ${ }^{\$ 3}$ Joan Mateu analiza los fenómenos de sedimentación y meandrización en la Ribera Alta y subraya la gran inestabilidad de la desembocadura del Albaida: «la confluencia del Albaida es un punto

80. Boscı JUŁı̇: Memoria ..., págs. 342-345.

81. Forués: Historia de Camcagente..., pág. i 51.

82. Episodio que citan MADOZ (Diccionario...) y J. SANCHIS SIVERA (Nomenclátor geográfico-eclesiástico cie los pueblos de la dícesis de Valencia, Valencia, Tipografia Moderna, 1922, pág. 238) entre otros autores.

83. SIGNES I NǴÑEZ: «Desbordaments del Xúquer desde l'any 1517», Festes Majors / Alcuidia. 1983; ForiUÉs JUAN: Historia de Carcagente..., pág. 152. 
de complejos ajustes hidráulicos. [...] Las repetidas divagaciones laterales del punto de confluencia del Albaida [...] reflejan, además, un punto crítico en el régimen sedimentario del llano de inundación, porque es el final del valle confinado»». ${ }^{84}$ Otra zona donde la dinámica de los meandros del Xúquer era muy intensa era la comprendida entre Alberic y Alzira, donde se estrangularon meandros como el del Toro y la Almunia. Pelufo expone que la riada del 6 de octubre de 1783 modificó substancialmente el trazado del Xúquer en el término de Alzira: «el río formó cauce nuevo, frente a la partida del Toro, dejando en seco el antiguo; lo mismo sucedió entre el puente de Sant Gregori y la partida de la Almunia, de manera que quedó inutilizado el camino del Toro y Alberique» ${ }^{85}$ Como el Xúquer hacía las veces de límite entre los términos de diversos municipios ribereños, estas variaciones ocasionaron pleitos muy costosos (uno de los mejores ejemplos es el de Castelló de la Ribera, estudiado por Vicent Ribes). ${ }^{86}$

\subsubsection{El impacto demográfico de las inundaciones}

\section{- Las victimas de las crecidas}

La expresión más dramática de los desbordamientos del Xúquer era las víctimas que ocasionaba, bien por ahogamiento o al hundirse sus casas. Tenemos noticia que esta circunstancia ocurrió en 1473, riada de la que V. Pelufo informa que produjo abundantes víctimas. Según este autor, en 1517 se ahogaron «algunas víctimas». Fogués informa que la inundación del 18 de septiembre de 1581 causó «muchas víctimas». En Algemesí, durante la riada del 19 de octubre de 1589, «se ahogaron algunas personas en sus mismas casas». Respecto el gran desbordamiento de 1632, Pelufo informa que fueron «muchas las personas que perecieron», lo mismo que durante la avenida de

84. MATEU Belles: «Cambios seculares de la agradación...», pág. 196.

85. Mateu Bellés explica con más detalle el impacto de estas mutaciones sobre caminos o acequias contiguas al río (art. cit, págs. 199-200). También hay que aludir a los cambios en la desembocadura del Xúquer, que complicaron la función portuaria de Cullera (Bosch Julià indica que, en la riada de 1864, «El Júcar en Cullera varió de dirección, siguiendo la que más directamente conduce sus aguas al mar. No deja de ser esto perjudicial a Cullera, pues, desaguando ahora por dos bocas o golas, hay poca profundidad de agua para la navegación de los buques de cabotaje, lo que obliga a efectuar el embarque y desembarque por medio de lanchones» (Memoria sobre la inundación..., pág. 357). Véase también sobre este punto Peris Albentosa: La terra de l'arròs i les moreres, págs. 200-203.

86. «Fins l'any 1765 el riu Xúquer, als Algoletges, un poc més avall d'on rep les aigües de l'Albaida, es dividia en dos braços, deixant al mig una ïlla. [...] Dit any el riu abandonà un dels braços [...], passant las noves terres a formar part del terme. [...] L'any 1780 [...aumentó] la superficie del terme gràcies a que el Xúquer ahandonà una altra porció de terres [...]. I el mes de febrer de 1788 fou l'Albaida el que canvià de caixer, abandonant el llit antic i deixant unes terres que els amos dels bancals contigus s'afanyaren en afegir a las seues propietats. [...] Totes aquestes variacions [...] devien legalitzar-se escrupolosament. donat que d'altra manera podien produir problemes de límits con los pobles veïns.[...] L'any 1790, els administrador's del duc de l'Infantado, senyor d'Alberic, pledejaven per unes terres a la vora del Xúquer pertanyents' a Castelló. I el 1783 era el comte d'Albalat, senyor de Beneixida, qui [...] ocupava més de 3.000 fanecades de Castelló i pretenia que foren considerades de Beneixida» (Rubes IBorRa: Secrets del Castelló set-centista..., págs. 221-223). 
aguas de $1776 .{ }^{87} \mathrm{Y}$ las autoridades alzireñas informan que durante las «avenidas e inundaciones del río Xúcar, [...] que se padecieron en los días 13 y 29 de marzo [de 1805 ...] se cayeron varias casas, pereciendo algunas personas entre sus ruinas» ${ }^{88}$

\section{- Cambios en la estructura del poblamiento}

Las endémicas riadas han ocasionado importantes modificaciones en la estructura de poblamiento de la Ribera. Hasta tal punto es así que debe considerarse al Xúquer como un elemento de primer orden en la vertebración del territorio, que ha obligado a evolucionar hacia una topología de hábitat cada vez más concentrado. En palabras de los geógrafos que se han ocupado del tema, «en el llano de inundación inmediato, unos diez núcleos fueron destruidos repetidamente y finalmente abandonados debido a sucesivas inundaciones, que se produjeron entre 1517 y $1779 »{ }^{89}$ En efecto, una serie de pequeñas alquerías ubicadas en la zona más expuesta a las riadas (la hondonada que drena el río Dels U1ls), como Tarragona, Cabanyes, Mulata, el Toro y Ressalany, fueron abandonadas y sus habitantes pasaron a vivir en núcleos menos expuestos. Igual proceso experimentaron Alàsquer, Alcosser, Benimexís, Ternils y Benimacli. El despoblamiento de estos últimos, así como los nexos causales con las riadas del Xúquer, fueron expuestos con tota nitidez por Francesc Fogués: «Como consecuencia inmediata de esta avenida vino la despoblación de Ternils y Benimacli, ya que sus habitantes pasaron a vivir a Carcagente, por estar situado en una meseta donde no llegaban las inundaciones $\gg .^{90}$ Cavanilles alude al abandono de Alcocer por efecto de las inundaciones del Xúquer: "Catorce años hace, aún existía Alcocer, con su iglesia, y buena parte de su población. Situado a la orilla del Xúcar, y no lejos de la confluencia de este río con el de Albayda, estaba siempre expuesto a inundaciones. Padecían los vecinos repetidas pérdidas sin escarmentar, caían edificios, quedaban sin cosechas sin desamparar sus hogares. Llegó en fin el término fatal, acabando con el pueblo las aguas de Sellent, Albayda y Xúcar». ${ }^{91} \mathrm{Y}$ el ilustrado V. I. Franco explica como los desbordamientos del Xúquer eran la principal causa que provocó la huida de pequeños núcleos: «Las frequentes avenidas del río Xúcar, las inundaciones que experimentaban los pueblos de Mulata, Toro, Puchol y Benimuslem; [...] la escasez de comestibles que padecían en la estación de lluvias y avenidas del río obligaron a los pobladores de Mulata, el Toro y Puchol a abandonarlos y dexar arruinar del todo y con muy poco vecindario a Benimusiem, trasladándose a la villa de Alcira, como la más inmediata, cuya dis-

87. PELuFo: «Inundaciones, terremotos y pestes». Por lo que se refiere a la riada del 4-5 de octubre del 1779 , MARTí SORO expone que apareció ahogado un molinero en el término de Castelló, aunque los muertos debieron ser bastantes más (GÓMEZ ORTEGA informa que en el pequeño pueblo de Cárcer perecieron ocho personas y 34 cabezas de ganado mayor; Estudio de las inundaciones del Jícar..., pág. 83).

88. Archivo Municipal de Alzira, Río Xúquer, $\mathrm{n}^{\circ}$ 15; Peris Albentosa: L'escenari i els protagonistes.... págs. 103-104.

89. ButZer-Miralles-MATEU: «Las crecidas medievales del río Júcar...», págs. 327-328.

90. Fogués: Historia de Carcagente..., págs. 150-151.

91. CAVANiLles: Observaciones..., vol. 1, págs. 196-198. 
tancia a sus haciendas es acomodada. [...] La proximidad a la villa de Alberique ha ocasionado la ruina del pueblo de Alasquer; y las avenidas del Xúcar la del antiguo Alcocer».92 Martí Soro explica que la inundación de 1773 originó el despoblamiento de Benimeixís, al marcharse a vivir sus habitantes a Senyera, y como la riada del 4 de octubre de 1779 destrozó Alcosser. El resultado de este proceso fue el tipo de poblamiento contemporáneo de la Ribera, caracterizado por ocupar los lugares mejor emplazados de cara a las avenidas fluviales: «una distribució lineal en ambdos marges del riu [...] es pot considerar una tipologia per a la Ribera Baixa que respon a peu de vessant (Cullera), a nuclis desenvolupats damunt un alter miocè (Sollana) o a pobles defensats per un dic o mota (Albalat de la Ribera, Polinyà) [...]. Pel que fa a la Ribera Alta, els pobles es troben en general més lluny del riu, excepció feta de Sumacàrcer $i$ Benimuslem $).^{93}$

\subsection{Un efecto positivo tan crucial como olvidado de las riadas del Xúquer: aportar sedimentos que ayudaban a mantener la fertilidad de los campos}

Como acabamos de ver, las consecuencias negativas de las riadas son bien evidentes, tanto para los ribereños de la época como para los estudiosos. Pero no podemos concluir afirmando que las inundaciones no tuvieran ninguna repercusión positiva, aunque este tipo de efectos resulte más difícil de percibir (hasta el punto de pasar desapercibidos entre las derivaciones catastróficas). Hay que destacar, sobre todo, la potente sedimentación inherente a las riadas del Xúquer, que ha transformado el paisaje de la Ribera, en especial los límites de la Albufera y la zona comprendida entre Alberic y Algemesí. Sin el aluvionamento del Xúquer, «la mayor part de la comarca seria avui una zona pantanosa plena de fangars; un aiguamoll albuferenc ple de joncs $\gg .{ }^{94} \mathrm{El}$ mismo Xúquer destructor ha contribuido -de forma decisiva- a hacer realidad el paisaje de agricultura intensiva que conocemos, no sólo por el agua que las acequias llevan hasta los campos sino también por el fango dejado por las riadas. V. I. Franco, un excelente conocedor de la comarca, explica las consecuencias positivas de las riadas con estas palabras: «Con el beneficio de estos ríos [Xúquer y Albaida], que con sus inundaciones fertilizan su suelo, goza esta villa del término más frondoso». ${ }^{95}$

Los fangos depositados por las riadas eran más valiosos de lo que Bosch Julià sospechaba. Este ingeniero forestal tenía razón cuando clarificaba que no todos los alu-

92. Cit. RIBEs IBORRA: La llustración murginada..., pág. 151.

93. M. J. TEIXIDOR DE OTTO y C. DOMINGO PÉrEZ: «El poblament i el riu Xúquer», Cuadernos de Geografía, n³2-33, 1983, pág. 138.

94. SIGNES I NÚNEZ: «Desbordaments del Xúquer...».

95. T. LOPEZ: Relaciones geográficas e históricas del reino de Valencia hechas en el siglo XVIII a ruego de don Tomás López. Las publica con notas, aumentos y comentarios Vicente Castañeda y Alcover, Madrid, Tipografia de la Revista de Archivos, bibliotecas y museos, 1919 (reed. Facsímil, Valencia, Consell Valencià de Cultura, 1998, pág. 76). 
viones arrastrados por el río eran excelentes..$^{96}$ Acierta cuando indica que la 'fanguina' que dejaban las aguas mataba a las plantas, así como que había que realizar importantes gastos para acondicionar los campos, nivelándolos para que pudieran seguir recibiendo el riego sin problemas. ${ }^{97}$ Pero no captó la enorme trascendencia que la mayor parte de los sedimentos depositados por el Xúquer tenía en una agricultura que sufría una drástica escasez de abonos (aunque llega a calificar a los aluviones como «limo reparador, fertilizante, compuesto de la flor de la tierra de los sitios elevados»). ${ }^{98}$

El Xúquer creaba muchos quebraderos de cabeza, pero también ayudaba a los campesinos de la Ribera a resolver los dos principales problemas de la agricultura de la época: la aridez crónica y el déficit de abonos. Por una parte, las acequias tomaban sus aguas y las hacían llegar a los campos cuando lo requerían los cultivos. Por otro lado, el limo dejado por las riadas era vital para mantener la fertilidad: impedía que los campos se vieran obligados a quedar en barbecho y contribuía a que pudieran dar varias cosechas cada año. ${ }^{99}$

En 1840, el síndico de la Acequia Real del Xúquer recalcaba los efectos benéficos de los desbordamientos. Expresaba que las «aguas extraordinarias del Júcar, conducidas por las grandes avenidas, proporcionan bienes incalculables a los pueblos de ambas riberas». Recalca que las aguas de las crecidas eran totalmente «necesarias para fertilizar sus campos», ya que «el limo del primero [Júcar] produce iguales efectos a los del segundo [Nilo]», és decir aportar «sales y sucos». ${ }^{100}$ Veinte años después, diversos representantes de las acequias de riego que funcionaban en la Ribera Alta destacaban los efectos positivos que ocasionaban las inundaciones del Xúquer. El síndico del duque de Hijar (constructor de la acequia del Proyecto, que amplió la acequia Real de Alzira desde Algemesí hasta Albal) señalaba que «estas inundaciones contribuyen a levantar el terreno, a desecarlo en alguna parte pantanosa y a salubrificarlo y hacerlo más fructífero produciendo [...], en cambio de daños pasageros, beneficios permanentes a los cuales debe indudablemente la Ribera del Júcar su aumento de riqueza y población»». ${ }^{101}$ En la misma época, J. Marín y L. Yáñez indicaban que:

96. Expresaba que «cuando las aguas del Júcar corren a rodolons por la Ribera baja, no contienen menos de diez kilógramos de materias terrosas por metro cúbicom, por lo que la cantidad de fangos depositados en la zona de máxima sedimentación (entre Alberic y Algemesi) debía ser muy superior (Memoria ..., pág. 83).

97. La Exposición de la Junta Administrativa de regantes de Alicante, del año 1841 , calculaba que los trabajos de extraer los aluviones estériles que dejados por el Xúquer en algunas zonas costaban «hasta 14 libras de plata del país, o [...] 210 reales de vellón [...] en cada hanegada de tierra» (en Exposiciones dirigidas a S. A. Serma, el Regente del Reino..., Valencia, Imprenta Orga, 1841, pág. 11).

98. Este mismo autor expone que el «fango que se saca de las acequias se llega a pagar a cuatro reales la barconada [30 espuertas de tierra] es un magnífico abono) (BOSCH JULİ̈: Memoria sobre la inundación del flicar.... págs. 83-91 y 230-233).

99. PERIS Albentosa: La terra de l'arròs i les moreres..., págs. 114-131.

100. Exposición del Sindico Procurador General de la Comunidad de Regantes de la Real Acequia de Alcira (1841), en Exposiciones dirigidas..., págs. 16-22.

101. Exposición dirigida al Excmo. Señor Ministro de Fomento por el Excmo. Sr. Duque de Hijar..., Valcncia, Imprenta José Rius, 1860, pág. 16. 
[...] las avenidas de invierno sirven para beneficiar los campos con los abonos que arrastran y para levantar progresivamente los terrenos bajos. [...] Las avenidas del Júcar son un bien grande [...] y poco importa que en las mayores crecientes desbarate algún pedazo de ribera, $[\ldots]$ que esto vale poco, muy poco, comparado con los inmensos beneficios que esas fecundantes y ambicionadas aguas nos traen en sus deseadas crecientes. [...] Las crecientes [...] en el invierno sirven, como las del Nilo, con el humus y con los estiércoles y despojos vejetales que arrastran, para beneficiar las muchas tierras que tienen escorrentía, para ir levantando el nivel de los terrenos bajos $[\ldots] .^{102}$

A. Sancho y L. Monleón expresaban, en 1860, los notables beneficios reportados por las riadas del Xúquer con las siguientes palabras:

$[\ldots]$ las avenidas, $[\ldots]$ lejos de ser perjudiciales a los labradores, les son sumamente beneficiosas, con especialidad en la parte baja de la Ribera, porque renuevan de una manera conveniente a la producción y a la salud pública la calidad de las aguas que habitualmente tienen las tierras pantanosas, y dejan en cuantas cubren excelentes depósitos de tierra virjen mezclada con sales y materias fertilizantes, que aseguran en los años inmediatos cosechas abundantes. [... En] los pueblos de la Ribera baja había antes [...] tierras encharcadas e insalubres que para nada servían, y las vemos hoy reducidas a labor rindiendo pingües productos, conociéndose cada vez más que las avenidas las levantan y desecan al paso que las abonan, to cual inspira a los labradores el constante afán con que procuran formar en las partidas malecones que detengan esas mismas aguas, a fin de que se consuman en ellas y las beneficien con sus depósitos [...]. ${ }^{103}$

Por último, Salvador Bodí Congròs (un carcagentino dotado de una gran capacidad de observación y perfecto conocedor de las características del clima y la agricultura de la zona), coincidía en señalar, en 1879, la relevancia agrícola de los depósitos dejados por los desbordamientos del Xúquer. A partir del análisis de la gran riada de 1864, explicaba como la corriente de las avenidas arrebataba de los montes y huertas ubicados aguas arriba «lo mejor de sus tierras», mientras que -por el contrario- dejaba en los campos de la Ribera «un depósito de arenas y humos [humus] en muchos puntos de considerable espesor. Este accidente ha servido de una positiva mejora, bonificando grandemente el término inundado [Carcaixent]». Constató «en la memorable avenida del año 1864 [... que en un] pequeño campo, en cuyas márgenes de su exutorio se encontraba una empalizada de membrilleros, [... quedaron] depositados a la entrada de las aguas preciosísimos y abundantes sedimentos de fertilizadas tierras, estiércoles amontonados, inmundicias utilizables a centenares de cargas». A partir de esta observación, tomó conciencia que los «abundantes y fertilizadores cienos» elevaban «el terreno cada vez más con preciosos sedimentos», abonando y mejorando «notablemente las campiñas». Por ello, recomendaba plantar «granados, membrilleros y otros árboles frutales con porte de arbusto en ambos márgenes» de las parcelas para evitar que «el ímpetu de la corriente de la inundación», durante las peores riadas, pudiera provocar

102. J. MARín y L. YÁÑEZ: Aptuntes breves y sencillos en impugnación de la larga memoria de don Juan Bautista Peyronet... Valencia, Imprenta Ayoldi, 1860, págs. 10-14.

103. SANCHO-Monleón: Dictamen facultativo..., pág. 19; J. M. FERRÁndiz y L. Yáñez, Apuntes breves y sencillos ..., pág. 10). 
el «violento arrebatamiento de las mejores capas de tierra labranticia» y propiciar que quedaran «enredadas en las numerosísimas y resistentes ramas de los arbustos [...] las pajas y despojos de las plantas y basuras arrastradas por las aguas, $[\ldots]$ dejando $[\ldots]$ incuestionable abonamiento del terreno, y el provechoso alzamiento». ${ }^{104}$

Algunos de los citados testimonios sobre los efectos positivos de las riadas del Xúquer se produjeron en el contexto de la polémica suscitada por diversos proyectos que pretendian trasvasar aguas del Xúquer hacia la provincia de Alicante, ${ }^{105}$ lo que obliga a verificar este tipo de afirmaciones. Pero las indicaciones de V. I. Franco o S. Bodí -perfectos conocedores de la Ribera y ajenos a este tipo de discusiones-parecen darles credibilidad. Habrá que investigar, pues, en esta línea si queremos efectuar un balance correcto de los efectos globales ocasionados por las inundaciones del Xúquer. ${ }^{106}$

\subsection{Las dificultades para precisar la jerarquia de riadas}

No resulta fácil concretar una jerarquía las riadas en función de la magnitud alcanzada. La dificultad se explica por la insuficiencia de los datos y porque en cada riada confluían muchas variables, la conjunción de las cuales es lo que acaba por explicar que tuviera unos efectos destructores o fuera, al contrario, bastante benigna e incluso beneficiosa. Un primer factor es el volumen de la crecida, concretado en el nivel alcanzado por las aguas y la fuerza de la corriente. Otro elemento a tener en cuenta es el tiempo que permanecían las aguas desbordadas. También es importante, a la hora de establecer la gravedad de la avenida, concretar la extensión de la zona afectada. La tipología de los desbordamientos varía desde crecidas locales hasta riadas que afectaron a buena parte de la comarca; desde inundaciones que sólo incumbían a las áreas agrícolas más hondas hasta otras que alcanzaron incluso a los núcleos urbanos más resguardados. El momento concreto del desbordamiento también resulta crucial de cara a establecer la desigual trascendencia de las riadas, ya que las pérdidas variaban enormemente según fueran los cultivos que ocupaban el territorio y el momento concreto del ciclo vegetativo en que cogía a las cosechas. Después de la siega del arroz, en septiembre, pocos frutos quedaban por recoger en los campos; por ese motivo, las riadas que afectaban a los cereales cuando ya estaban a punto de segarse siempre resultaban muy dramáticas. Una circunstancia que agravaba el efecto de las avenidas se daba cuando la corriente arrastraba los millares de troncos de pino que bajaban flotando por el río o se encontraban amontonados en las orillas del Xúquer en determinados puntos ('eixugadors'). Finalmente, los perjuicios agrícolas eran muy distintos según si la inundación se producía cuando otras adversidades climatológicas -como temporales

104. S. Bodi: El ctima de la Ribera..., págs. 75-78.

105. Peyronet transformó el proyecto inicial de captar unos quiméricos sobrantes del Xúquer en otro plan que pretendía tomar «las aguas de las crecidas ordinarias [del Xúquer] para alimentar constantemente un canal durante siete u ocho meses al añon).

106. Tampoco puede olvidarse que otra consecuencia positiva que se experimentaba los años de inundación del Xúquer era el aumento considerable de pesca en la Albufera. 
de lluvia, pedriscos, etc.- ya habían destrozado los cultivos o si se estaba a las puertas de recolectar una excelente cosecha.

Un procedimiento que tiene a su favor un alto grado de objetividad consiste en estudiar el registro geoarqueológico de los sedimentos depositados por el río. Butzer, Miralles y Mateu realizáron este tipo de análisis en Alzira y Pilar Carmona -recientemente- en diversos puntos de la Ribera. Pero la secuencia estratigráfica de !os aluviones es una primera referencia que permite concretar la energía de la corriente durante la crecida, pero no cómo afectaron las aguas a las comunidades humanas que ocupaban el territorio. Esta metodología ha constatado tres niveles sedimentarios que corresponden a sendos episodios de inundación catastrófica acaecidos al final del siglo XV o principio del XVI, postrimerías del quinientos o inicios del XVIl y, finalmente, un conjunto de avenidas destructoras en el siglo XIX.107

La documentación histórica permite afinar un poco más la percepción del fenómeno de las riadas históricas del Xúquer y sus efectos en la comarca de la Ribera. ${ }^{108}$ Un primer criterio para tratar de establecer la gravedad de las inundaciones es la alusión a víctimas, hecho destacado por la bibliografía consultada para los desbordamientos de $1473,1517,1581,1589,1632,1776$ y 1779 . El nivel alcanzado por las aguas es otro dato fundamental a ser tenido en cuenta, pero que se concreta pocas veces. Sabemos que la corriente subió entre 15 y 18 metros sobre el nivel ordinario durante la riada de 1632. Otras inundaciones para las que disponemos de detalles precisos sobre la fuerte crecida de las aguas son las de 1779 y 1805 . Para el resto de avenidas de aguas, las noticias que proporciona la bibliografía son lacónicas ${ }^{109}$ o nulas. Los desbordamientos de mayor duración parecen ser los de 1590 (año con 22 inundaciones), 1627 (cuando las aguas se mantuvieron fuera del lecho durante 20 días), 1672 (el Xúquer desbordó 11 veces en menos de 90 días), los tres últimos meses de 1714, la fase 1779-83 y -finalmente- la crecida de 1795. En base a la insuficientes noticias de que disponemos, puede aventurarse que las riadas más destructoras parecen ser las de $1473,1517,1571,1632,1672,1779,1805,1831$ y 1864 (también cabe destacar los desbordamientos de 1589 y 1776$).{ }^{119}$

\section{LAS RESPUESTAS A LAS INUNDACIONES}

La reacción histórica a las riadas del Xúquer ha sido bien humana, es decir, contradictoria y impulsiva, pero mucho más sosegada de lo que pudieramos imaginar $a$ priori.

107. BUTZER-MIRALLes-MATEU: «Las crecidas medievales...», págs. 326-327.

108. PERIS Albentosa: L'escenari i els protagonistes.... págs. 99-120.

109. Como la del 1714, riada de la que Fogués indica que «alcanzó considerable altura» (Historia de Carcagenté..., pág. 156).

110. Sorprende que una de las pocas riadas en que se llega a especificar que no causó graves daños sea la de 1791, que Cavanilles describió con tintes melodramáticos, seguramente a causa de no estar acostumbrado a vivir episodios semejantes (Observaciones..., vol. I, pág. 194). 


\subsection{La sorprendente tranquilidad ante las inundaciones del Xúquer}

Las enérgicas reacciones suscitadas en los momentos más dramáticos que se vivían durante las inundaciones extraordinarias y extremas chocaban con la complejidad del problema. Las limitaciones técnicas y económicas hacían difícil poner en marcha cualquier actuación, siempre polémica. Además, los años normales -intercalados entre riada y riada- eran todo un estímulo a dejar dormir cualquier proyecto, lo que explica la inconstancia de los vecinos de la zona y la pasividad de los oficiales de la corona, hechos que ya denunciaba Llansol al final del siglo XVIII:

Ya estos años pasados el Ayuntamiento hizo presente al Real Consejo la situación crítica y peligrosa en que se hallaba esta villa [Alzira] por las avenidas del Xúcar, y el sabio tribunal mandó que se buscasen todos los medios para liberarla de estos peligros, se hicieron y planificaron algunos proyectos, y entre otros el de quitar las azudes y el molino, que es lo primero que se viene a la vista. Útil es el proyecto, pero poco ventajoso por quitar sólo una causa de las muchas que concurren y he insinuado; sin embargo, ni aún esto se ha executado, y los moradores de Alcira, como otros tantos Jonases, se han echado ya a dormir en medio del más inminente riesgo. Así lograra yo dispertarles con la facilidad que ellos se duermen. ${ }^{111}$

Sorprende sobremanera -y obliga a reflexionar- la tradicional calma y serenidad con que los vecinos de la Ribera reaccionaban ante el comienzo de un desbordamiento del Xúquer. Un informe municipal de Alzira, del año, 1802 relata como hasta el final del setecientos prevaleció un ambiente caracterizado por la ausencia total de dramatismo:

[...] esta villa, por su situación local, ha sufrido siempre en su término las inundaciones del Xícar, pero no se observava que entrasen las aguas con tanta altura en ella, sin riesgo de ningún vecino, antes bien solia ser de diversión del público. Pero en el día se ven subir a una altura de más de seis palmos sobre el nivel antiguo y baxar por las calles con una rapidez peligrosa, de modo que los vecinos que antes tenian un día de solaz cuando entrava el Xicar en la villa, se ven oy día tímidos y tristes por las funestas experiencias de las desgracias acaecidas. ${ }^{12}$

¿Como explicar que el inicio de un desbordamiento hubiese sido durante generaciones y generaciones motivo de solaz y regocijo para los alzireños? ¿Cómo entender que cuando las aguas del Xúquer comenzaban a inundar las calles de Alzira (muestra, pues, que se trataba de una riada importante) los vecinos no tomaran este hecho como una desgracia o una amenaza sino como una jarana amena y una algazara tranquila?

111. LlANSOL: Topografia médica general..., págs. 107-108.

112. Dicho informe continuaba atribuyendo el agravamiento de los efectos de los desbordamientos al efecto barrera ejercido por camino Real Valencia-Madrid ( «Es verosímil que este aumento de aguas proceda del empuje que causa el camino Real de Madrid a las que se derramavan por las almarxales, las que ahora son impelidas hacia las villas de Alcira y Carcagente, en cuyo lugar no entravan antes las aguas del Xúcar, y en el dia son muchísimas las que le inundan en todas las avenidas»), diagnóstico que corrobora lo tardio de la aparición de reacciones angustiadas ante las inundaciones (Archivo Municipal de Alzira, Río Xúquer, n"15). 
Algún motivo debían tener para tomarse el asunto con tanta serenidad. No debía tratarse de pura irresponsabilidad, sino que hay que pensar que algún tipo de beneficio reportaría la corriente desbordada del río. A pesar que los efectos nocivos de las inundaciones siguieron agravándose durante las últimas décadas del setecientos y primeras del XIX, la riada de Sant Carles de 1864 todavía cogió a los ribereños demasiado confiados ante el peligro que les amenazaba. Como Bosch Julià comenta, sólo reaccionaron cuando ya el nivel de las aguas había crecido de manera tan rápida como angustiosa, sin dar tiempo a salvar los enseres más preciados de la casa: la «ciega confianza fue la causa de muchas pérdidas y desgracias que se deploran. A nadie se le ocurrió poner a salvo los muebles y animales domésticos. A la una de la tarde cesó la lluvia, pero la invasión de las aguas en las casas se hizo general. Entonces todo el mundo se alarmó» ${ }^{113}$

\subsection{Las limitadas respuestas para paliar los efectos de las riadas}

Las actuaciones de los pueblos ribereños estuvieron caracterizadas por la solidaridad más visceral en los momentos dramáticos y el individualismo más feroz a la hora de abordar cualquier política de defensa frente a las riadas. Una muestra representativa de los habituales comportamientos solidarios fue la respuesta de los vecinos de Alberic para ayudar a los de Alcosser en 1785, que recoge Madoz:

$[\ldots]$ quedando aquel pueblo aislado por espacio de dos o tres días; en estos apuros los vecinos de Alberique les prestaron un servicio inapreciable; montaron en caballos y nadando les socorrieron con pan y viandas, y aun les fueron sacando y trasładando a sus casas, no ocurriendo más desgracia que la de una familia que vivía en el estremo del pueblo, cuya casa recibía de lleno el ímpetu de las aguas. ${ }^{114}$

Cuando, pasados los momentos más terribles de la riada, se trataba de buscar soluciones de futuro, los proyectos que acabaron ejecutándose carecían de cualquier tipo de planteamiento global, comarcal. Todos se limitaban al objetivo de tratar de paliar los efectos de las riadas en el propio pueblo, sin reparar si con ello se agravaban los problemas de los núcleos vecinos.

La respuesta más frecuente era que todo quedara en una momentánea rebaja de impuestos, que hiciera más soportable sobrellevar las circunstancias, algún acto caritativo que mantuviera lo más tranquilas posible a las capas más humildes de la sociedad y poco más. Proyectos e ideas hubo algunos. Actuaciones, pocas y siempre de tipo local. La más usual fue construir motes, unos diques de defensa con los cuales se pretendía proteger a las poblaciones frente a las riadas ordinarias, en las que el nivel de la crecida era modesto. Benimuslem, Carcaixent, Polinyà, Riola, Albalat y Fortaleny construyeron sus motes. ${ }^{115}$ Algemesí también levantó defensas hidráulicas de este tipo.

113. BOSCH Julia: Memoria .., pág. 339.

114. P. MADOz: Diccionario geográfico-estadistico-histórico de Alicante, Castellón y Valencia (reed. selectiva de las voces correspondientes al País Valenciano del Diccionario Geográfico-Estadístico-Histórico de España y sus posesiones en Ultramar editado en Madrid el 1845-50), Valencia, Alfons el Magnànim. 2 vols, 1982, vol. 1, voz 'Alberique'.

115. TEIXIDOR-DOMINGO: «El poblament i el riu Xúquer», págs. 146-147. 
Si hacemos caso de la cronología, las motes parecen más consecuencia de la necesidad de resolver el problema de donde acumular los sedimentos dejados por el río que fueran poco aprovechables desde el punto de vista agrícola (o una versión rural de los «murs $i$ valls» de la cercana ciudad de Valencia) que una clara influencia de técnicas monzónicas traídas por los misioneros jesuitas. J. A. Domingo recoge la existencia de motes en Algemesí ya en 1589. ${ }^{116} \mathrm{Y}$ en Carcaixent hubo, desde final del quinientos, una institución municipal de «Murs $i$ Valls» encargada de realizar obras de defensa para proteger el término de las riadas del Xúquer. ${ }^{117} \mathrm{~F}$. Fogués describe los valls de Carcaixent como «amplios terraplenes» y alude al acuerdo del Consejo General de 1596 para rehacer unos diques que estaban deteriorados ( $L$ Lo vall que està fet a Sant Sebastià per que guarde del riu Xúquer, està romput i també altres valls a la vora del dit riu i convé tornar-los a fer; $i$ s'acordà que se tanque dit portell $i$ altres que estan a la vora, de pedra $i$ crosta, conforme està fet el abeuradory). ${ }^{118}$ El propio Racsas, al recomendar actuaciones para solucionar el problema de las riadas, propuso generalizar los diques que havia visto en Riola y Carcaixent:

Otro remedio será ensanchar la madre del río donde hubiere necesidad [...] y de la misma tierra que de ahí se sacare hacer motas o diques apartadas de la ribera cincuenta pasos comunes como las que hay en el término de Riola y las han comenzado en Carcagente [...]. Hanse de hacer estos diques o ribazos no de sola tierra sino mezclada arena y bien pisados y trabados con estacas que por lo menos tengan de ancho en lo alto 11 ó 12 palmos $[\ldots] .{ }^{119}$

A partir de experiencias previas y las recomendaciones de los hidraulistas que participaron en el conflicto de 1635, se construyeron más motes en la Ribera. Así, las autoridades municipales de Algemesí mandaron realizar, en 1651, unas obras de acondicionamiento del lecho del río que consistían en dragar el fondo y reforzar las márgenes con «motes $i$ paredons». ${ }^{120}$ Las motes resultaban deterioradas durante las crecidas más importantes, razón por la que era necesario realizar constantes trabajos de mantenimiento. Así, la riada de 1779 afectó a Carcaixent porque se rompieron los diques que protegían a este pueblo, ${ }^{121}$ pero las motes se reconstruyeron y mejoraron inmediatamente, estado en el que las conoció el Dr. Llansol cuando escribía su Topografia en $1797 .^{.22}$

Racsas, como propuestas para solucionar o reducir los efectos perniciosos que ocasionaban los desbordamientos extraordinarios del Xúquer, propugnó eliminar los azudes, ensanchar «la madre del río donde hubiere necesidad» y construir diques pro-

116. J. A. DOMINGO i BORRÀs: «Les nostres riuades...», págs. 18-20.

117. FoguÉs: Historia de Carcagente..., pág. 172.

118. Fogués: ibidem.

119. MATEU BELLÉs: «La ciència i la tècnica...»》, pág. 248.

120. DOMNGO । BORRÀS: «Les nostres riuades...».

121. FoGUÉs: Historia de Carcagente..., pág. 152.

122. Llansol comenta la existencia, al final del siglo XVIII, de un dique o «malecó» en Carcaixent que desviaba las aguas del Xúquer hacia Alzira (LLANSOL: Topografia médica..., págs. 107-108). 
tectores de $3 \mathrm{~m}$. de altura. Por último, encargaba «sangrar por alguna parte el río, $[\ldots]$ un poco más debajo de Alcira hacia Corbera», a fin de facilitar el curso de las aguas desbordadas en su tránsito hacia el mar. ${ }^{123}$

El agravamiento de las riadas que comenzaron a percibir los habitantes de la Ribera durante las últimas décadas del siglo XVIII i comienzo de la siguiente centuria estimuló a adoptar algunas medidas puntuales más con las que paliar los efectos negativos de las peores riadas, como manifiesta el informe municipal elevado por las autoridades alzireñas en 1802, en el que se propone eliminar el molino municipal emplazado dentro del río Xúquer. ${ }^{124}$ Con todo, cabe esperar a la resaca provocada por la grave inundación de 1864 para encontrar los primeros proyectos globales. Bosch Julià proponía realizar en las inmediaciones de Alzira las siguientes actuaciones:

[...] mucho ganaría Alcira con la rectificación del cauce del Júcar en sus inmediaciones; con la desaparición de los azudes, logrando de esta manera ahondar 2 metros el lecho del río; con cortar el brazo derecho del Júcar y terraplenar el foso; con ensanchar el cauce del barranco de Barcheta [...]; con ensanchar la población hacia la Montañeta de San Salvador; con edificar con arreglo a las prescripciones del arte. La abertura de canales de desagüe en las inmediaciones de las Casas de Moncada y de Campanar forzosamente habria de aliviar a Alcira $[\ldots]]^{125}$

Pero la comisión que este ingeniero forestal presidía recomendó a Isabel II adoptar medidas globales para atenuar las inundaciones del Xúquer en el conjunto de la Ribera. Destacan esta serie de propuestas de actuación con las que concluye la Memoria sobre la inundación del Júcar...:

1. a Se poblarán de monte los terrenos de la cuenca hidrográfica del Júcar dentro de la provincia de Valencia [...].

123. Cit. MATeu Belles: «La ciència i la tècnica...», pág. 248.

124. Dicho documento sigue informando que «se permitió que se cerrasen dos grandes canales que havía cerea de las dos puentes de San Agustin y de San Gregorio, que davan salida a las aguas antes de entrar en los arcos de ambos puentes, [...] y se establecieron ciertas casas frente [de manera que...] han subido considerablemente las aguas, por no poder pasar libremente por los arcos de puente con tanta copia como vienen, y se ven obligadas a entrar dentro las calles con una rapidez increíble [... Y] creen, sin duda, que era también necesario romper las asudes que llevan el agua al molino dicho de la Villa, para que se desenterrasen los arcos del puente de más de diez y seis palmos de arena que están sepultados sus arranques [...]. Testigo Don Patricio Barberá, ciudadano. [... Es] cierto y manifiesto a todos los vecinos de Alcira, los quales muchos años hace que se quexan de los perjuicios que sienten los campos y las casas de esta villa desde el tiempo que se fueron terraplenando los fosos y se edificaron las casas que hay junto a ellos [...], haviéndose edificado allí casas y cerrado los fosos, se le obliga ahora a pasar toda por el puente de San Gregorio, donde hay establecidos a los arcos dos grandes azudes para torcer el río acia el molino, no pudiendo pues caber toda el agua en este cause, salta al otro brazo que rodea el pueblo; alli, al llegar al Puente de San Agustin, tenía antes la otra grande canal que vaciava el agua antes de entrar por los arcos del puente y no eran oprimidos estos. Mas, como en el día se han cerrado estos conductos y se han edificado casas que impiden el curso de las aguas, se entran muchas más por las calles abiertas derribando algunas, como sucedió en el día trece de marzo próxime pasado, en la que cayeron tres en la calle de la Sangre» (Arxiu Municipal Alzira, Río Jícar, 1, n 15, ff. 1-6).

125. BOSCH JuLiȦ: Memoria ..., págs. 342-345. 
2. ${ }^{a}$ Se harán desaparecer los malecones (motas) que existen entre Alcira y las Casas de Moncada, y entre Albalat de Pardines y Sueca [...].

4. ${ }^{\text {a }}$ Se dará a los cauces las dimensiones necesarias para contener las aguas de las avenidas ordinarias $[\ldots]$.

5. ${ }^{a}$ Se harán desaparecer los obstáculos que impidiendo el curso expedito de las aguas corrientes y levantando el lecho de los ríos [...] favorecen los desbordamientos.

6. ${ }^{2}$ Se harán desaparecer igualmente las grandes sinuosidades del curso de las aguas que entorpecen la marcha de las corrientes y ocasionan el que se depositen grandes cantidades de cascajo o arenas [...].

8. ' Se cegará el brazo derecho del Júcar en Alcira y se hará desaparecer la presa de la misma localidad.

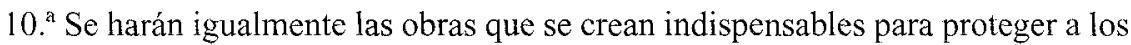
pueblos muy expuestos a las inundaciones, como Carcagente, Alcira, Albalat y otros construidos en sitios muy bajos.

11. ${ }^{\text {a }}$ Se someterán a las condiciones de construcción que se crean convenientes las casas que en lo sucesivo se edifiquen en las poblaciones de la Ribera expuestas a las inundaciones, tanto en lo que concierne a la solidez como a la elección del sitio.

12. "Se prohibirá depositar maderas en las orillas de los ríos [...].

14. ${ }^{\text {a }} \mathrm{El} 15$ de octubre se habrá hecho desaparecer de las tierras arrozales y sitios bajos que estén al alcance de las aguas de las avenidas la paja de arroz y las cañas de maíz $[\ldots]$. $^{126}$

Algunas de estas propuestas se realizaron años después, ${ }^{127}$ pero muchas de ellas nunca llegaron a aplicarse y las inundaciones del Xúquer siguen siendo un peligro nada quimérico que amenaza a una Ribera ya industrial y terciaria. También constituyen un interrogante abierto a los investigadores que pretendan matizar la visión exclusivamente catastrofista que hasta ahora ha predominado.

126. Memoria..., págs. 396-398.

127. J. F. MATEu BeLLés: «Les obres de defensa de la División del fícar, 1864-1935», ponencia a la $X$ Assemblea d Historia de la Ribera, Antella 5-7 noviembre de 2004. 